\title{
High-resolution longitudinal serum proteome trajectories in COVID-19 reveal patients-specific seroconversion
}

\section{Graphical Abstract}

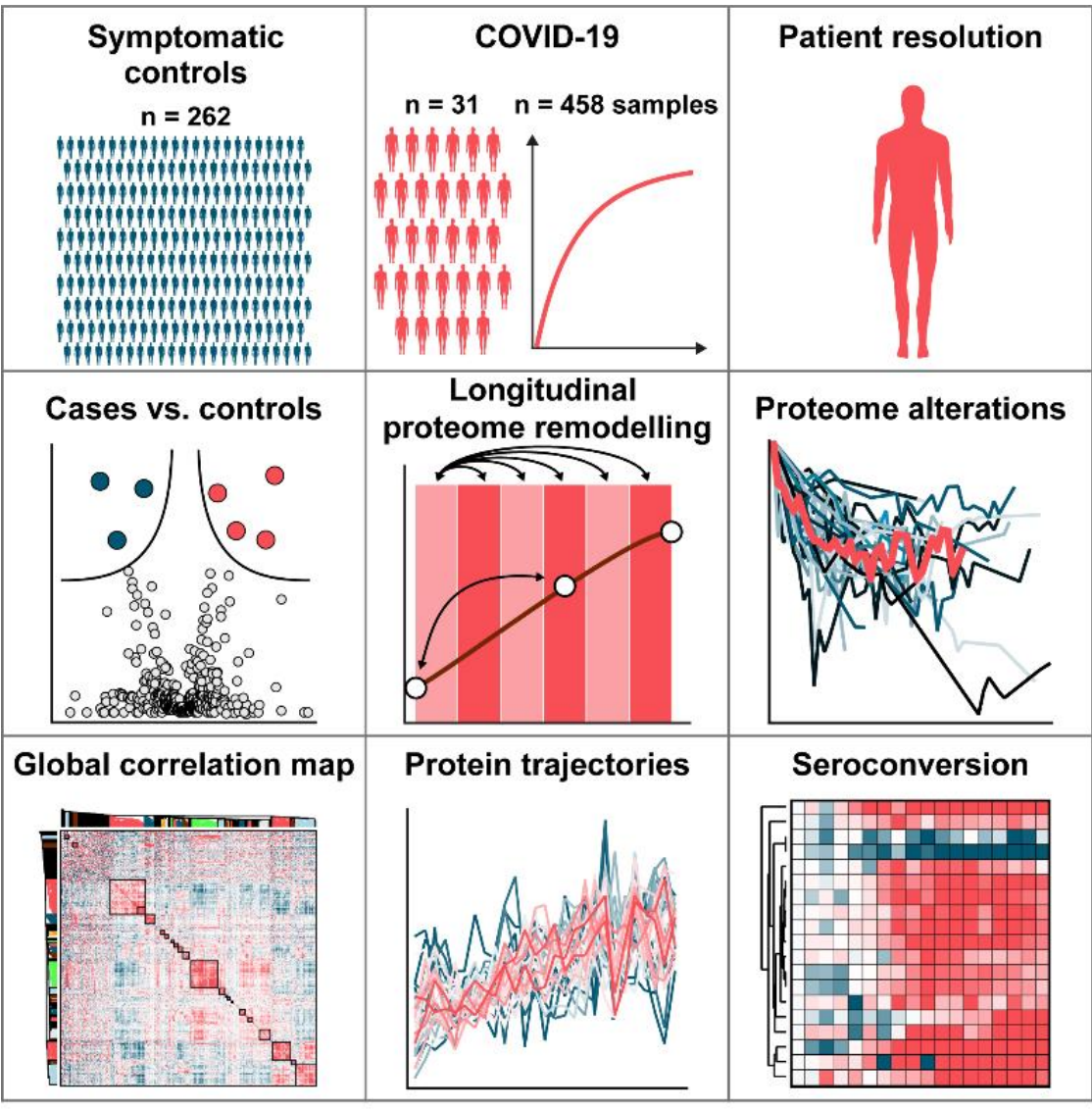

\begin{abstract}
Authors
Philipp E. Geyer, Florian M. Arend, Sophia Doll, Marie-Luise Louiset, Sebastian Virreira Winter, Johannes B. Müller-Reif, Furkan M. Torun, Michael Weigand, Peter Eichhorn, Mathias Bruegel, Maximilian T. Strauss, Lesca M. Holdt, Matthias Mann, Daniel Teupser
\end{abstract}

\section{Correspondence}

Geyer@OmicEra.com

Daniel.Teupser@med.uni-muenchen.de

\section{Keywords}

Biobanking, biomarker, immunoglobulins, individual-specific, quality, SARS-CoV-2

\section{Highlights}

- A total of 720 proteomes of 262 symptomatic controls and 458 longitudinal samples (average 31 days) of hospitalized COVID-19 cases were analyzed

- $26 \%$ of the 502 quantified proteins significantly changed in COVID-19 patients

- The innate immune and the coagulation system were strongly regulated

- MS-based profiles of immunoglobulin regions allow the detection of seroconversion in a highly detailed fashion on the patient level

- ITIH4 may be a prospective marker of COVID-19 mortality 


\title{
High-resolution longitudinal serum proteome trajectories in COVID-19 reveal patients-specific seroconversion
}

\author{
Philipp E. Geyer ${ }^{1 *}$, Florian M. Arend², Sophia Doll ${ }^{1}$, Marie-Luise Louiset ${ }^{2}$, Sebastian \\ Virreira Winter ${ }^{1}$, Johannes B. Müller-Reif ${ }^{1}$, Furkan M. Torun ${ }^{1}$, Michael Weigand ${ }^{2}$, Peter \\ Eichhorn², Mathias Bruegel $^{2}$, Maximilian T. Strauss ${ }^{1}$, Lesca M. Holdt' ${ }^{2}$, Matthias Mann², \\ Daniel Teupser ${ }^{2 *}$
}

\section{Abstract}

Biomarkers for COVID-19 are urgently needed. Here we bring the powerful technology of mass spectrometry (MS)-based proteomics to bear on this challenge. We measured serum proteomes of COVID-19 patients and symptomatic, but PCR-negative controls, in a timeresolved manner. In 262 controls and 458 longitudinal samples (average of 31 days) of 31 patients, hospitalized for COVID-19, a remarkable $26 \%$ of proteins changed significantly. Bioinformatics analyses revealed co-regulated groups and shared biological functions. Proteins of the innate immune system such as CRP, SAA1, CD14, LBP and LGALS3BP decreased early in the time course. In contrast, regulators of coagulation (APOH, FN1, HRG, KNG1, PLG) and lipid homeostasis (APOA1, APOC1, APOC2, $A P O C 3, P O N 1)$ increased over the course of the disease. A global correlation map provides a systemswide functional association between proteins, biological processes and clinical chemistry parameters. Importantly, five SARS-CoV-2 immunoassays against antibodies revealed excellent correlations with an extensive range of immunoglobulin regions, which were quantified by MSbased proteomics. The high-resolution profile of all immunoglobulin regions showed individual-specific differences and commonalities of potential pathophysiological relevance.

\section{Introduction}

The pandemic associated with the severe acute respiratory coronavirus type 2 (SARS-CoV-2) has spread around the globe with massive impact on mankind. By now, coronavirus disease 2019 (COVID-19) has infected and killed millions (https://covid19.who.int/). Thanks to the tremendous efforts of the global scientific community, the virus has been extensively investigated and new tests for pathogen detection and potential treatments have been rapidly developed (Wiersinga et al., 2020).

The clinical presentation of COVID-19 is characterized by a variety of symptoms (Wiersinga et al., 2020). The most common manifestations are fever (89\%), cough (58\%) and dyspnea (45\%) (Rodriguez-Morales et al., 2020). This is mirrored by rather non-specific laboratory findings, such as decreased albumin, elevated C-reactive protein (CRP) and lymphopenia, which are also commonly seen in other viral diseases. A rather characteristic feature of COVID-19, particularly in severe cases, is venous thromboembolism, which occurred in up to $59 \%$ of patients in an intensive care unit setting (Middeldorp et al., 2020). On a mechanistic level, dysregulated platelets and neutrophils cooperate to drive a systemic prothrombotic state, indicating inflammation as a trigger for thrombotic complications. As an important laboratory finding, the fibrin degradation product d-dimer was strongly elevated in COVID-19 and correlated significantly with disease severity (Nicolai et al., 2020). Another hallmark of COVID-19 is the formation of virus-specific antibodies, which peaked within three weeks after symptom onset (Long et al., 2020; Buchholtz et al.,

${ }^{1}$ OmicEra Diagnostics GmbH, Planegg, Germany

${ }^{2}$ Institute of Laboratory Medicine, University Hospital, LMU Munich, Munich, Germany

${ }^{3}$ NNF Center for Protein Research, Faculty of Health Sciences, University of Copenhagen, Copenhagen, Denmark

*To whom correspondence should be addressed: Geyer@OmicEra.com or Daniel.Teupser@med.uni-muenchen.de 
medRxiv preprint doi: https://doi.org/10.1101/2021.02.22.21252236; this version posted February 23, 2021. The copyright holder for this preprint (which was not certified by peer review) is the author/funder, who has granted medRxiv a license to display the preprint in perpetuity.

All rights reserved. No reuse allowed without permission.

Research Article

Serum protein trajectories in COVID-19

2021). While currently available routine laboratory tests give important diagnostic cues and have contributed to a better understanding of the pathophysiology, they only provide an incomplete picture of humoral changes in COVID-19.

Proteins control and execute the vast majority of biological processes, and specific alterations in protein levels typically accompany disease onset and progression. Mass spectrometry (MS)-based proteomics is the method of choice to globally investigate proteins in a biological system - its proteome (Aebersold and Mann, 2016). In this sense, MS-based proteome analysis of plasma and serum is unbiased and in principle an ideal technology for systemswide characterization of disease response (Geyer et al., 2017). In practice, body fluid proteomics is very challenging but continuous technological improvements have led to a resurgence of interest (Geyer et al., 2017; Ignjatovic et al., 2019; Suhre, McCarthy and Schwenk, 2021).

Several groups have analyzed the serum or plasma proteome of COVID-19 infected patients (D'Alessandro et al., 2020; Messner et al., 2020; Park et al., 2020; Shen et al., 2020; Shu et al., 2020). These were generally smallscale studies with single or few time points. As a general trend, the levels of complement components and inflammation proteins tended to increase whereas proteins of the coagulation cascade tended to decrease when compared to control groups. One study investigated a relatively large number of plasma samples in a longitudinal study design to develop predictive models but also reported alterations linked to inflammatory response, metabolic reconstitution and immunomodulation (Demichev et al., 2020).

The aim of our study was to use MS-based proteomics to discover new potential biomarkers and provide a better understanding of the underlying pathophysiology of COVID19. To this end, we set out to measure protein trajectories in unprecedented detail in a longitudinal cohort of COVID19 patients. This involved plasma proteome profiling of 720 serum proteomes of patients hospitalized with COVID-19 symptoms and controls. To efficiently and rapidly analyze this large sample set, we developed a very robust workflow based on a recently described 'clinical grade' liquid chromatography (LC) system (Bache et al., 2018) with a novel trapped ion mobility - time-of-flight mass spectrometer (timsTOF) (Meier et al., 2018). This allowed the characterization of 60 serum proteomes per day. The study design followed our recently proposed 'rectangular strategy', where samples are measured in as great a depth as routinely possible, and biomarker patterns are extracted from the entire study population (Geyer et al., 2017). This further allowed the assessment of sample or analysis quality issues, such as contamination with blood cells or coagulation (Geyer et al., 2019). Furthermore, aggregated into global correlation maps, the data identify co-regulated factors, physiological processes and enable integration with other clinical results (Albrechtsen et al., 2018; Geyer et al., 2019; Ignjatovic et al., 2019). We previously noted that the levels of most plasma proteins are specific to an individual, making longitudinal studies particularly informative. As each individual serves as its own control, this effectively corrects for inter-individual variations, increasing the likelihood to discover true regulations of protein levels (Geyer, Albrechtsen, et al., 2016; Dodig-Crnković et al., 2020).

In this work, we first describe differences between the serum proteomes of COVID-19 patients and those with apparent COVID-19 symptoms who were PCR negative. We then derive highly detailed time-resolved disease trajectories of serum proteins with on average 15 time points, covering up to 54 days in blood sampling. This study design allowed us to investigate various aspects of the host response to COVID-19 infection as reflected in differences between disease trajectories, longitudinal protein changes and immunoglobulin production. We disentangle these with global correlation maps that also include detailed clinical chemistry parameters. In particular, the cohort had measurements with five different anti-SARS-CoV-2 immunoassays against antibody classes, enabling us to inspect correlations between these immunoassays and the corresponding MS-detected serum proteins. Our results show that protein levels follow complex patterns and suggest that biomarker tests would benefit from incorporating individual timelines and individual-specific protein levels. We discuss implications of our measurements for our understanding of the antibody-based and individual responses of COVID-19.

\section{Results}

\section{Study overview and serum proteome analysis}

To draw a detailed picture of the dynamic nature of circulating proteins in response to COVID-19, we investigated longitudinal blood serum samples of 31 COVID-19 patients, as well as single time point samples of 262 SARS-CoV-2 PCR-negative controls (Fig 1A). 
medRxiv preprint doi: https://doi.org/10.1101/2021.02.22.21252236; this version posted February 23, 2021. The copyright holder for this preprint (which was not certified by peer review) is the author/funder, who has granted medRxiv a license to display the preprint in perpetuity. All rights reserved. No reuse allowed without permission.

Research Article

Serum protein trajectories in COVID-19

A

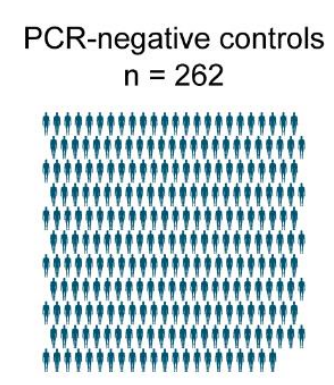

D

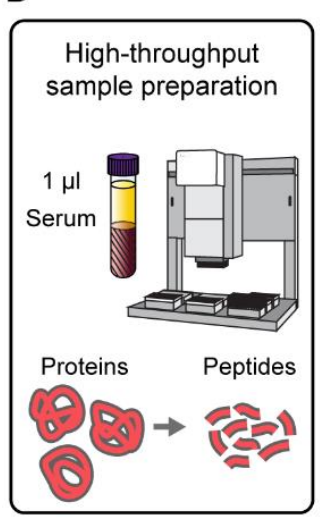

$\mathrm{F}$

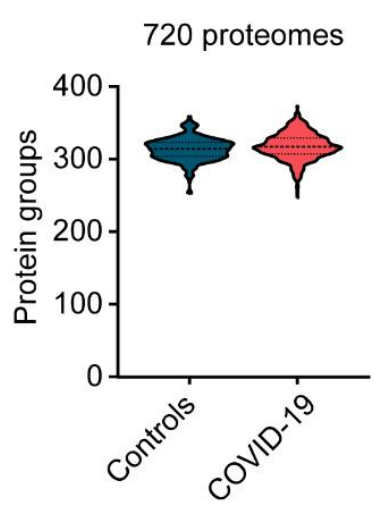

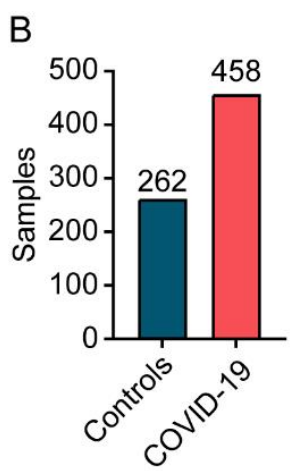
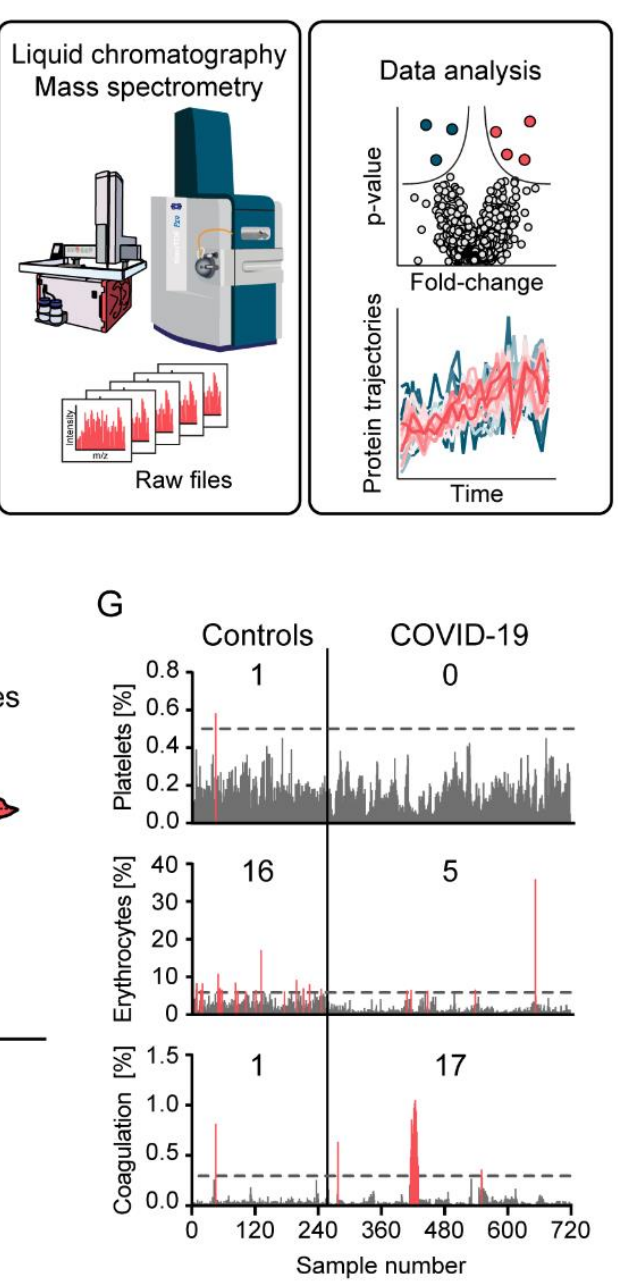

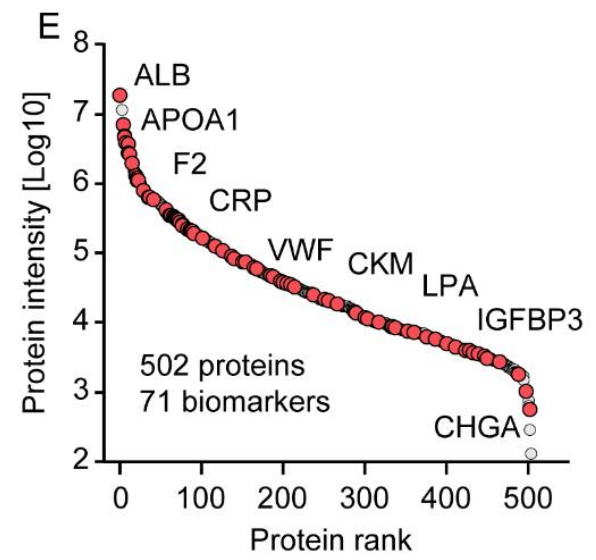

$\mathrm{H}$
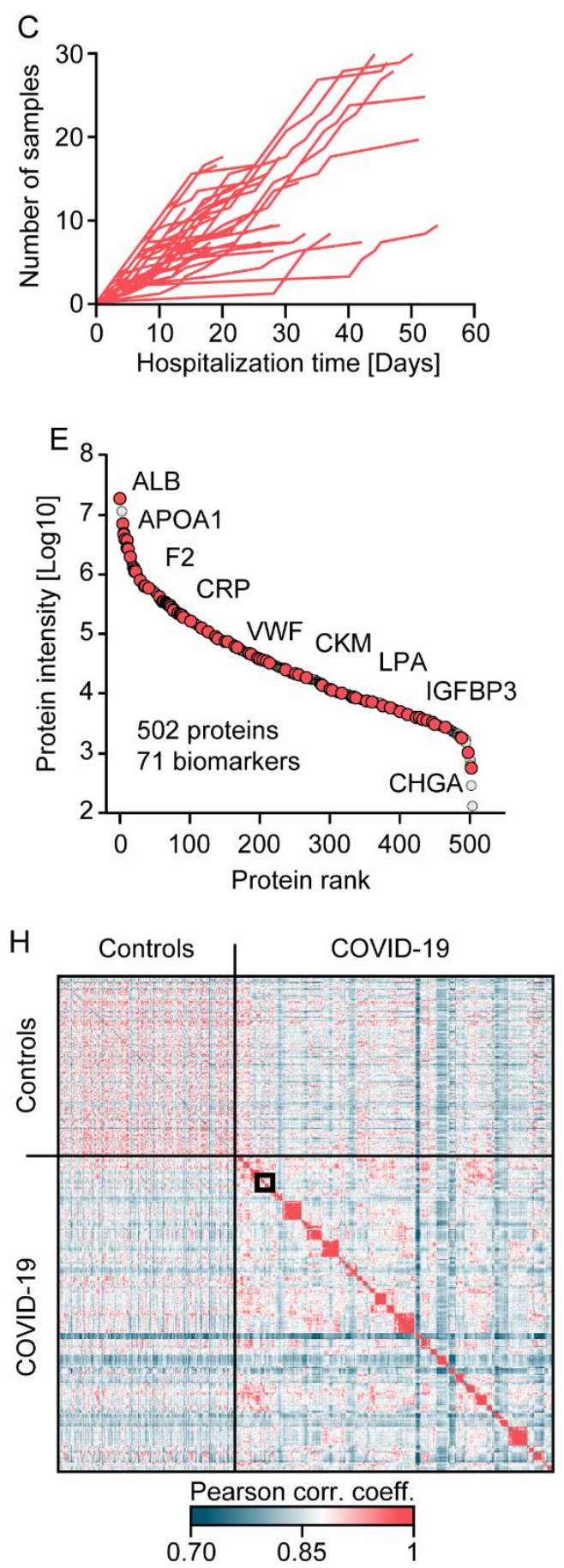

\section{Fig 1 - Study overview and serum proteome analysis}

A. Overview of the study cohort, including 262 SARS-CoV-2 PCR-negative control patients with single time point samples and 31 COVID19 patients with longitudinal samples collected during the period of hospitalization.

B. Total numbers of samples within each study group.

C. Longitudinal trajectories of the covered time in days (x-axis) and the number of available samples (y-axis) for each patient.

D. Automated MS-based proteomics pipeline starting with $1 \mu \mathrm{l}$ of serum, LC-MS instrumentation to generate MS raw data and data analysis. 
medRxiv preprint doi: https://doi.org/10.1101/2021.02.22.21252236; this version posted February 23, 2021. The copyright holder for this preprint (which was not certified by peer review) is the author/funder, who has granted medRxiv a license to display the preprint in perpetuity.

All rights reserved. No reuse allowed without permission.

Research Article

Serum protein trajectories in COVID-19

E. In total, 502 proteins were quantified in this study, covering more than five orders of magnitude of MS signal. Clinically applied biomarkers are highlighted in red. Examples of these biomarkers are labeled.

F. Violin plots representing the numbers of quantified proteins in individual serum samples of PCR-negative controls and COVID-19 positive patients.

G. Quality assessment of each sample according to main contamination sources of serum (Geyer et al., 2019). Intensities of samples with contamination indicators above a designated cut-off are highlighted in red and the numbers of samples exceeding these levels are displayed.

$\mathrm{H}$. Cross-correlation of quantitative protein levels across all 720 proteomes. Longitudinal samples within individuals are arranged in consecutive order along the axes. A zoom-in of the framed area is depicted in Fig 4E.

Patients presented at the University Hospital of the LudwigMaximilian University (LMU) Munich with COVID-19-like symptoms. Among a total of 720 samples, 458 were from the 31 COVID-19 patients with an average of 14 samples ( 7 to 30 ) per individual over an average period of 31 days (14 to 54) (Fig 1B-C).

Applying recent technological progresses of streamlined MS-based proteomics and an automated sample preparation procedure, allowed protein digestion and peptide purification of 720 study samples within a single working day (Fig 1D) (Geyer, Kulak, et al., 2016) (Material and Methods). For peptide separation, we used an Evosep One LC system in which peptides are first immobilized on a small volume of disposable $\mathrm{C} 18$ tip material without carryover, eluted into preformed gradients and finally separated on a relatively short and robust analytical column with minimal overhead between injections. Mass analysis used the PASEF acquisition principle on a timsTOF instrument, enabling very high sequencing speed and therefore data completeness (Meier et al., 2015, 2018; Bache et al., 2018). Across all 720 samples, we quantified a total of 502 proteins (Fig 1E). The median number of quantified proteins in samples from COVID-19 positive patients and PCR-negative controls in this rapid method were $312( \pm 18)$ and $308( \pm 16)$, respectively (Fig $1 F)$. The dataset contained 71 clinically applied biomarkers for a wide range of indications (Table EV1).

As a first analysis step, we assessed the quality of all samples according to our previously established quality marker panels in order to pinpoint samples with potential issues in pre-analytical processing. One sample was contaminated with platelets, 21 had evidence of erythrocyte lysis and 18 had signs of impaired coagulation (Fig 1G, Fig EV1) (Geyer et al., 2019). Furthermore, we detected increased erythrocyte protein contaminations in the control group compared to the COVID-19 patient samples (5 vs. 21 samples). Upfront knowledge of these issues turned out to be important as it allowed us to highlight these proteins as potential sources of bias in our further analysis (Fig EV2AC). As intra-individual variation is expected to be smaller than inter-individual variation, we used a correlation of the 720 proteomes to each other for a global consistency check. Indeed, the large majority of longitudinal samples showed higher correlation within than between individuals (Fig $1 \mathrm{H}$, Fig EV3, see below).

\section{Serum proteome differences of COVID-19 patients and SARS-CoV-2 PCR-negative controls with COVID-19-like symptoms}

Our hypothesis was that alterations of serum protein levels specific to COVID-19 might enable the differentiation of COVID-19 patients from patients with COVID-19-like symptoms. This was the basis for collecting samples of SARS-CoV-2 PCR-positive and -negative patients. The latter presented with COVID-19-like symptoms such as fever, cough, shortness of breath, throat pain, loss of smell and taste, fatigue, general malaise, gastrointestinal complaints, headache, cognitive impairment, need of oxygen or intensive care treatment because of respiratory symptoms.

Comparing the serum proteomes between the two groups on the first day of sampling resulted in 37 proteins with significantly altered levels of which 14 showed increased and 23 decreased levels in COVID-19 patients (Fig 2A, Fig EV2A, Table EV2). Proteins increased in COVID-19 patients included typical innate immune system mediators such as complement factors C2, C9, C4BPA, alpha-1-acid glycoprotein 1 (ORM1), monocyte differentiation antigen CD14 and galectin-3-binding protein (LGALS3BP). Plasma protease $\mathrm{C} 1$ inhibitor (SERPING1) was the most significantly regulated protein ( $p$-value: $1.7^{*} 10^{-11} ; 1.5$-fold) 
medRxiv preprint doi: https://doi.org/10.1101/2021.02.22.21252236; this version posted February 23, 2021. The copyright holder for this preprint (which was not certified by peer review) is the author/funder, who has granted medRxiv a license to display the preprint in perpetuity. All rights reserved. No reuse allowed without permission.

Research Article Serum protein trajectories in COVID-19

and CD14 was the protein with the highest fold-change ( $p$ : $2.4^{*} 10^{-10} ; 2.1$-fold) in COVID-19 patients compared to PCRnegative controls. Moreover, a group of protease inhibitors, including SERPING1, SERPINA3, SERPINA10, ITIH3 and ITIH4 were increased in COVID-19 patients. Likewise, coagulation factor $V(F 5)$ was significantly increased in COVID-19 patients, whereas modulators of coagulation such as the beta-2-glycoprotein $1(\mathrm{APOH})$, histidine-rich glycoprotein (HRG) and fibronectin (FN1) were decreased. Proteins of the lipid homeostasis system, especially components of high-density lipoprotein (HDL) particles such as APOA1, APOA2, APOA4, APOC1, APOD, PLTP and LCAT were also significantly decreased in COVID-19 patients. APOH was the most significantly regulated of these ( $p: 2.5^{\star} 10^{-16} ; 1.9$-fold) and the cysteine-rich secretory protein 3 (CRISP3) was the protein with the highest foldchange in PCR-negative controls ( $p$ : $1.1^{*} 10^{-4} ; 2.9$-fold). Proteins differentially expressed between both groups confirm several findings from former studies, especially the protease inhibitors, proteins of lipid homeostasis and factors of the immune system (D'Alessandro et al., 2020; Messner et al., 2020). We also replicated the regulation of gelsolin (GSN), which has been highlighted in previous MSbased proteomics studies. However, GSN ranked at position 34 and was only borderline significant at the first day of sampling ( $\mathrm{p}: 1.6^{*} 10^{-4} ; 1.3$-fold).

To investigate alterations of the serum proteome of COVID19 patients at a later time point to PCR-negative controls, we leveraged the extensive antibody testing that had been performed in our study. We selected the sample of each patient that had the highest level of SARS-CoV-2 antibodies based on the Roche S-Ab test. Comparison at this point, which occurred on average $21( \pm 12)$ days after first sampling, resulted in 34 significantly different proteins (Fig 2B, Fig EV2B, Table EV3). At this later time points, in contrast to the first one, GSN had the most significantly decreased levels ( $p: 1.2^{*} 10^{-11} ; 1.7$-fold) whereas the group of coagulation system proteins described above was not significantly different at this time point.

HDL particle proteins were consistently lower also at this time point in COVID-19 patients, among which APOD (p: $4.2^{*} 10^{-10} ; 1.9$-fold) and APOA2 (p: $1.6^{*} 10^{-5} ; 1.5$-fold) were statistically significant. These examples indicate the advantages of investigating the proteome in a longitudinal fashion as distinct proteins were regulated at distinct time points during disease progression.
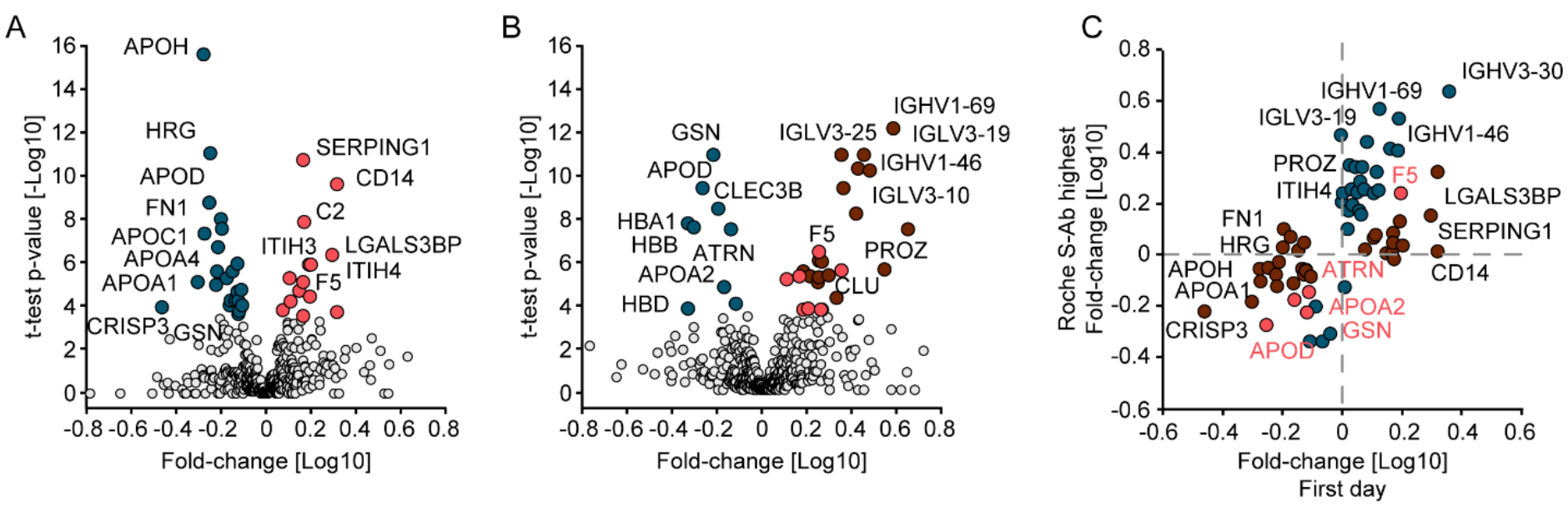

Fig 2 - Serum proteome differences of COVID-19 patients and SARS-CoV-2 PCR-negative controls with COVID-19-like symptoms

A. Volcano plot comparing the serum proteomes of 31 COVID-19 patients at the first day of sampling to those of the 262 PCR-negative controls. Significantly up-regulated proteins in COVID-19 positive patients are highlighted in red and down-regulated proteins in blue. The $\log 10$ fold-change in protein levels is represented on the $x$-axis and the - $\log 10 t$-test $p$-value on the $y$-axis.

B. Volcano plot comparing the serum proteomes in samples from COVID-19 patients at the time point of highest Roche S-Ab levels to PCR-negative controls. Significantly up-regulated proteins in COVID-19 positive patients are highlighted in red and down-regulated proteins in blue. Significantly up-regulated immunoglobulin regions are highlighted in dark red.

C. Scatter plot of protein fold-changes in (A) vs. those in (B). Significant proteins of (A) are highlighted dark red, those of (B) in blue and significant in both in bright red. 
medRxiv preprint doi: https://doi.org/10.1101/2021.02.22.21252236; this version posted February 23, 2021. The copyright holder for this preprint (which was not certified by peer review) is the author/funder, who has granted medRxiv a license to display the preprint in perpetuity.

All rights reserved. No reuse allowed without permission.

Research Article

Serum protein trajectories in COVID-19

With a total of 19 out of the 34 differently expressed proteins, immunoglobulins were the group of proteins that showed the most elevated levels in COVID-19 patients. This reflects the antibody test results but at a much more granular level (see below). Only five proteins were significantly different between the comparisons of both the first day of sampling and the day of highest Roche S-Ab levels with the PCR-negative controls (F5, ATRN, GSN, APOD, APOA2) (Fig 2C), providing a clear indication of a massive rearrangement of the serum proteome during the course of the disease.

\section{Regulated serum proteins in the disease course of COVID-19}

To understand the degree and nature of serum proteome remodeling during the disease course in infected patients, we performed three statistical analyses on our dataset (Fig 3A). For all comparisons, we considered the first day of sampling as a baseline. We used a one-sample t-test, because proteins vary in an individual-specific manner (Geyer, Albrechtsen, et al., 2016; Dodig-Crnković et al., 2020).

First, we investigated differences between the first day of sampling (early disease stage) and the time point with the highest host antibody response as determined by the Roche S-Ab assay. Disease progression between the two time points was accompanied by systemic effects on the serum proteome with 38 decreased and 44 increased proteins (Fig 3B, Fig EV2C, Table EV4).

The most significantly decreased proteins included the complement factors $\mathrm{C} 2$ ( $\mathrm{p}: 6.1^{*} 10^{-7} ; 1.6$-fold) and CFB (p: $1.0^{*} 10^{-6} ; 1.3$-fold) whereas FN1 (p: $1.4^{*} 10^{-8} ; 2.0$-fold) and $\mathrm{APOH}$ (p: $1.7^{*} 10^{-8} ; 1.9$-fold) increased most significantly. The median fold-change of significantly regulated proteins was 1.6 from the first day to the day with the highest Roche S-Ab level. As a group, the downregulated proteins were dominated by factors of the inflammation system, including 18 proteins annotated with the Gene Ontology Biological Process (GOBP) term "immune system process", which included serum amyloid A-1 protein (SAA1; $p: 3.6^{*} 10^{-4} ; 5.2$-fold), C-reactive protein (CRP; p: $6.3^{*} 10^{-4}$ : $3.2 ; 4.9$-fold), serum amyloid $A-2$ protein (p: $5.2^{*} 10^{-3} ; 4.7$-fold), CD14 (p: $3.8^{*} 10^{-5} ; 2.1$-fold) and lipopolysaccharide-binding protein (LBP; p: $3.5^{*} 10^{-6}$; 2.1 -fold). Notably, increased proteins were dominated by immunoglobulins with 20 different regions (see below). In addition to $\mathrm{APOH}$ and $\mathrm{FN} 1$, the coagulation regulators $\mathrm{HRG}$ (p: $2.1^{*} 10^{-5} ; 1.6$-fold), CPB2 (p: $1.1^{*} 10^{-3} ; 1.2$-fold), PROZ (p: $3.4^{*} 10^{-3} ; 1.9$-fold) and TTR (p: $4.5^{*} 10^{-4} ; 2.0$-fold) clearly increased, as did a group of apolipoprotein $C$ proteins (APOC1 (p: 5.9*10-6; 1.7-fold), APOC2 (p: 1.3*10-5; 1.9-fold), APOC3 (p: 3.2*10-5; 1.6-fold)).

Second, we explored regulations of serum protein levels over time, which revealed 34 highly significant positively and 39 highly negatively correlated proteins ( $p$-value $<10^{-4}$ ) (Fig 3C, Table EV5). Proteins showing the highest positive correlation were ITIH2 (p: 6.4*10-27; Pearson correlation R: 0.47), ITIH1 (p: 7.8*10-21; R: 0.42), APOH (p: 5.3*10-16; $\mathrm{R}: 0.37$ ) and FN1 (p: $2.8^{*} 10^{-19} ; \mathrm{R}: 0.40$ ). Proteins showing the highest negative correlation were LGALS3BP (p: 3.6*10-18; R: -0.39), C2 (p: 2.0*10-17; R: -0.38), L-selectin (SELL; p: $4.7^{*} 10^{-16}$; R: -0.40 ) and ORM1 (p: 5.8*10-14; $\mathrm{R}$ : -0.34). These data demonstrate a strong, coordinated response of the serum proteome over the time course of infection.

Third, to investigate more complex protein trajectories in COVID-19 infection, we conducted one-sample t-tests across five-day intervals (Fig 3D). This resulted in 28 significantly regulated proteins (Fig 3D, Table EV6) in addition to those correlating with sampling time alone. Interestingly, after binning samples in five-day intervals, there were no significant changes from day 0 to days $1-5$ and the first significant changes were detected when comparing to days 6-10. Strong regulations were found between day 0 and the later intervals up to the days 26-30 (Fig 3D/E). The coagulation associated proteins described above were again the most significantly increased ones, but the binned time course analysis added AZGP1 and KNG1 to this group. The most significantly decreased proteins consisted of complement factors such as C8A, C8B, CFB, C2 and $C 9$ in the 11-15 and 16-20 days intervals and other inflammation proteins such as ORM1, ORM2, LBP, CD14, LGALS3BP and CRP in the later intervals.

Together, these three time-resolved analyses (Fig 3B/C/D) implicate that a large proportion of the quantified serum proteins (130 out of 502) in diverse biological processes are 
medRxiv preprint doi: https://doi.org/10.1101/2021.02.22.21252236; this version posted February 23, 2021. The copyright holder for this preprint (which was not certified by peer review) is the author/funder, who has granted medRxiv a license to display the preprint in perpetuity.

All rights reserved. No reuse allowed without permission.

A

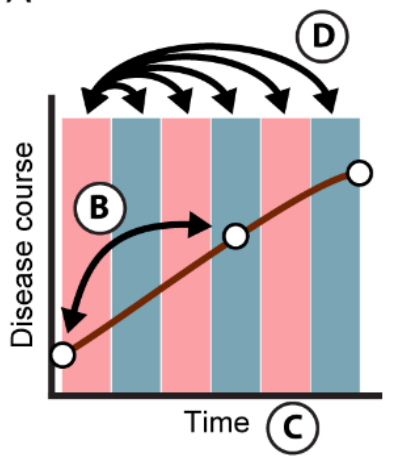

B

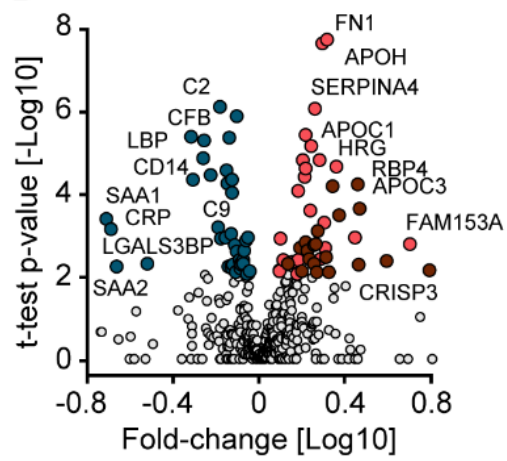

C

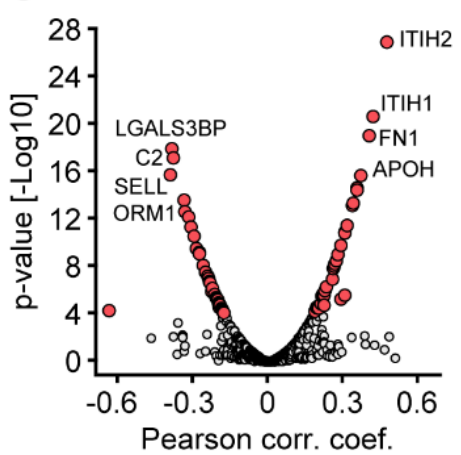

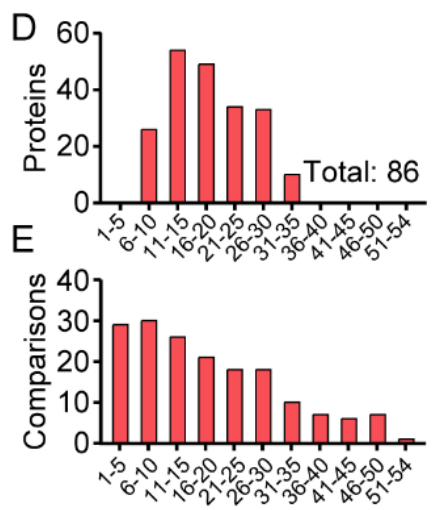

Fig 3 - Identification of proteins altered in COVID-19

A. Schematic of how proteins were compared across disease trajectories. Letters correspond to the panels in this figure.

B. Volcano plot of the results of a one-sample t-test comparing the sample at the first day of sampling and the time point with the highest antibody levels. Blue colored proteins are significantly down- and red ones up-regulated over time. Immunoglobulins are highlighted in dark red. The fold-change in protein levels is depicted on the $x$-axis and the -log10 t-test p-value on the $y$-axis.

C. Correlation of proteins with sampling time during hospitalization. Pearson correlation coefficients and -log10 p-values are displayed on the $\mathrm{x}$ - and $\mathrm{y}$-axes, respectively. Proteins significantly correlating with sampling time (positively or negatively) and a $\mathrm{p}$-value $<10^{-4}$ are highlighted in red.

D. Numbers of significantly altered proteins between the first day of sampling (day 0 ) and subsequent time intervals (binned days on the $\mathrm{x}$-axis), determined by one-sample t-tests.

E. Numbers of samples per interval subjected to the one-sample t-test in (D).

significantly altered in the course of COVID-19. This highlights both the extensive rearrangement of central physiological proteins and that these can be assessed by proteome profiling.

\section{High-resolution trajectories and clusters of differentially regulated proteins in COVID-19}

Following the analysis of COVID-19 cases against controls as well as binned and grouped time intervals described above, we inspected protein trajectories of all COVID-19 patients in high-resolution. Reducing the time span to a maximum of 37 days (for which we had at least five patients per sampling day), resulted in 116 proteins with significant changes along the trajectories. This revealed three major clusters: (1) broadly decreasing, encompassing 51 proteins, (2) broadly increasing (35 proteins) and (3) broadly increasing, followed by a decrease (30 proteins) (Fig 4A). As the Z-scored trajectories substantially overlapped, Fig $4 \mathrm{~B}$ shows all of them in the form of a heatmap, preserving full resolution of all proteins and time points.
For biological interpretation of regulated proteins, we tested the 116 regulated proteins with keywords and Gene Ontology Biological Process (GOBP), Molecular Function (GOMF) and Cellular Component (GOCC) using Fisher's exact test. This resulted in 409 significant associations between the keyword and GO term categories, corresponding to 51 keywords, which were further reduced to 20 non-overlapping terms (Material and Methods, Table EV7). Enzymatic activity was one of the main reported regulations indicated by proteins with keywords "Proteases", "Protease inhibitors", "Zymogen" and "Hydrolases". The keyword "Protease" had the highest number of annotations (25 proteins), reflecting the regulation of plasma protease inhibitors, coagulation factors and the complement system. Other frequent annotations included "Transport" (21 proteins), followed by "Immunity" (19 proteins), "Complement-pathway" (15 proteins), "Metalbinding" (15 proteins) and "Blood-coagulation" (12 proteins) (Fig 4C).

Applied to the three clusters of temporally regulated proteins, the results of Fisher's exact test revealed that cluster 1 contained proteins of the innate immune system such as CRP, SAA1, CD14, ORM1, ORM2, LBP, 13 
medRxiv preprint doi: https://doi.org/10.1101/2021.02.22.21252236; this version posted February 23, 2021. The copyright holder for this preprint (which was not certified by peer review) is the author/funder, who has granted medRxiv a license to display the preprint in perpetuity. All rights reserved. No reuse allowed without permission.

A
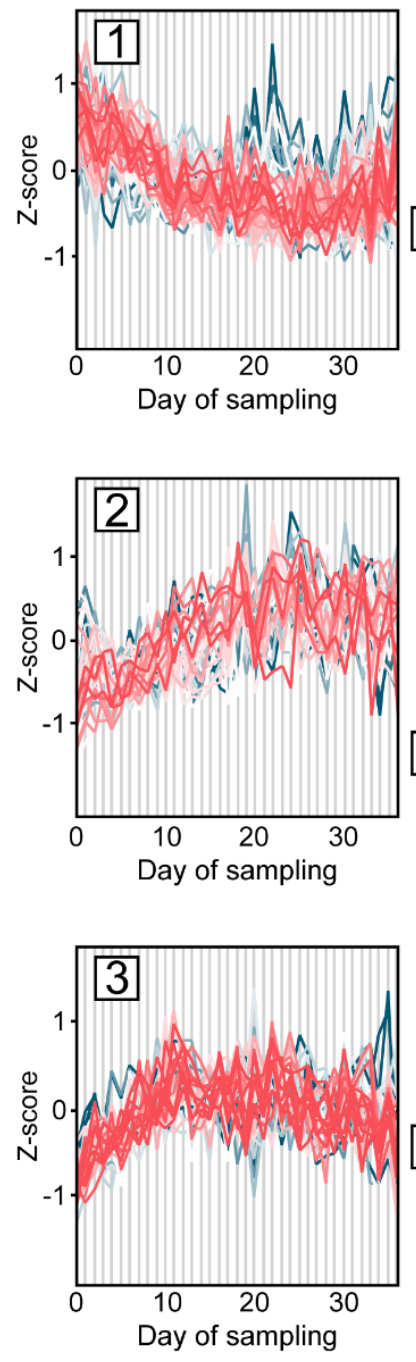

B

Time [Day]

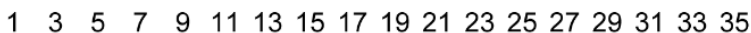

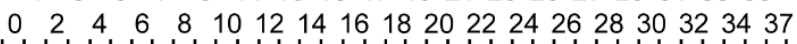

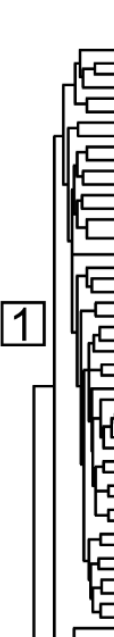

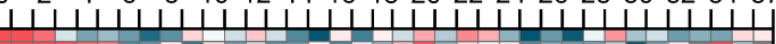

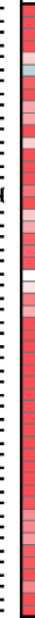

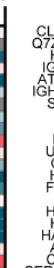

C
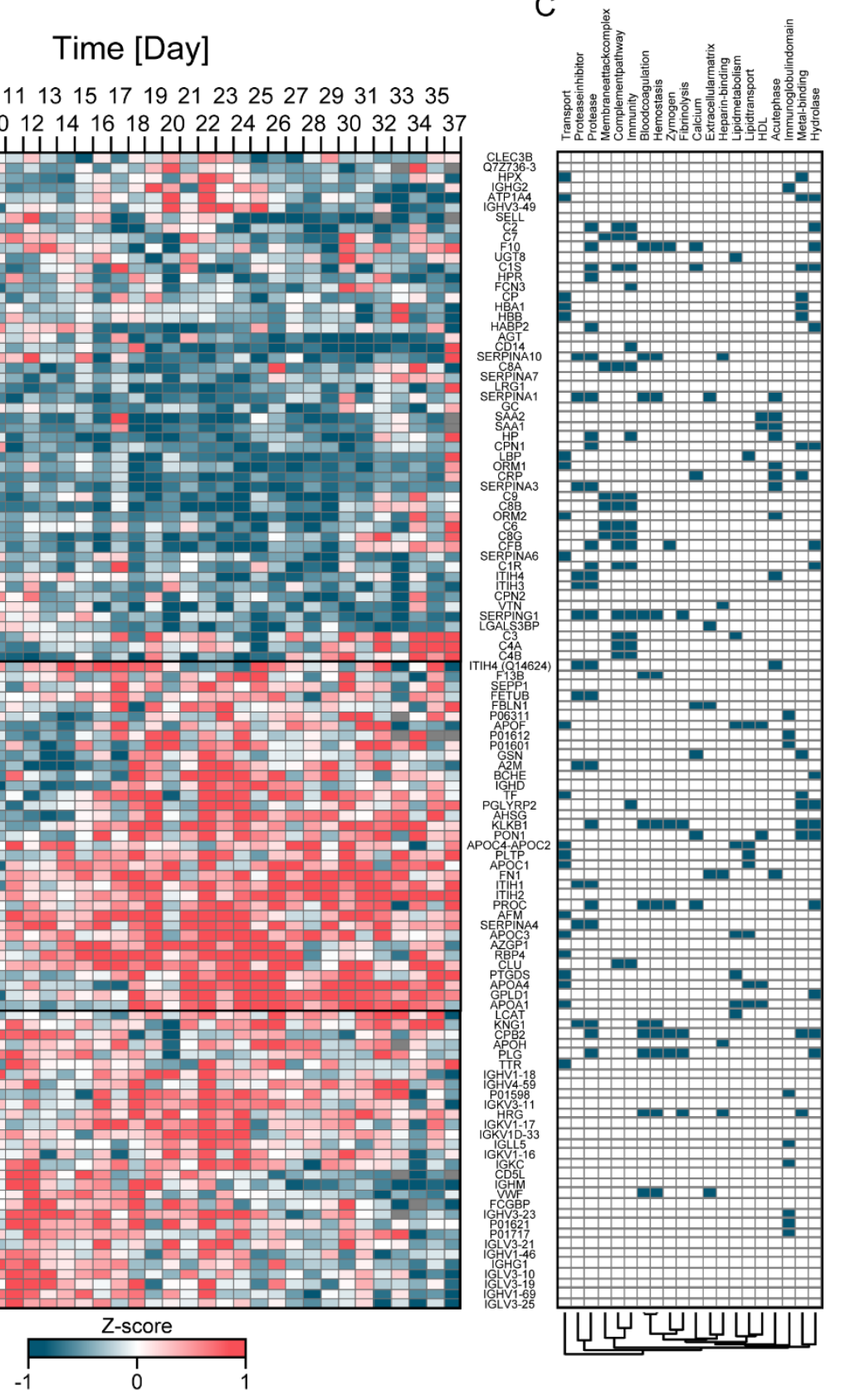

D

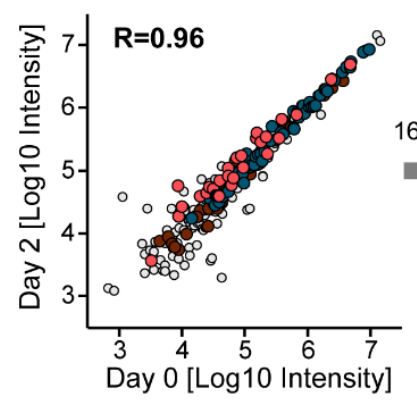

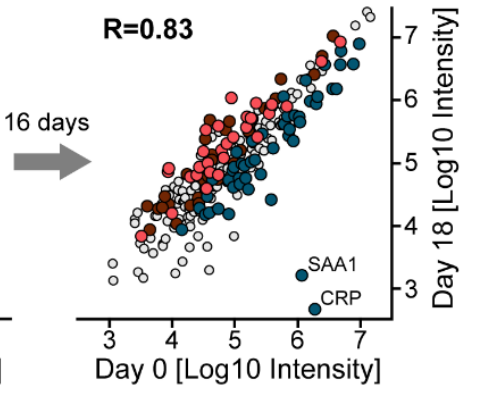

E

ㅇ ㄴ $0 \wedge \infty \stackrel{\infty}{\circ}$

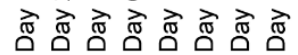

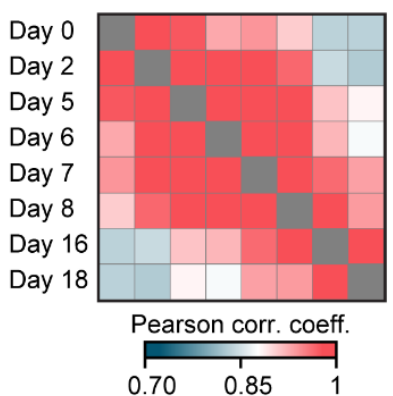

F

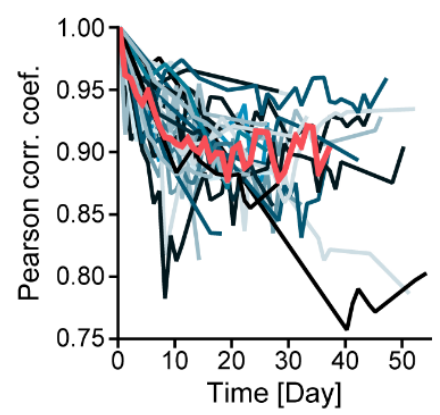


medRxiv preprint doi: https://doi.org/10.1101/2021.02.22.21252236; this version posted February 23, 2021. The copyright holder for this preprint (which was not certified by peer review) is the author/funder, who has granted medRxiv a license to display the preprint in perpetuity.

All rights reserved. No reuse allowed without permission.

Research Article

Serum protein trajectories in COVID-19

\section{Fig 4 - Longitudinal trajectories and extent of proteome alterations in COVID-19}

A. Longitudinal trajectories of the 116 proteins that significantly changed over the disease course of up to 37 days and were quantified in at least five of 31 COVID-19 patients. Trajectories were clustered into three main groups by Euclidian distance after Z-scoring and were color-coded by distance from the cluster center to highlight outliers (blue).

B. Longitudinal protein trajectories in COVID-19 over the sampling time of up to 37 days represented as a heatmap and clustered as in (A).

C. Main keywords associated with regulated proteins. Keywords were identified in a Fisher's exact test on all 116 proteins and then subjected to hierarchical clustering (Material and Methods).

D. Scatter plot of the serum proteomes of one patient at the first day of sampling (day $0, x$-axis) compared to day 2 (left panel) and day 18 (right panel). Proteins of the clusters 1, 2, 3 described above are highlighted in blue, dark red and bright red, respectively.

E. Color-coded Pearson correlation coefficients for all samples of the same patient as in (D). The panel is a zoom-in of the framed area in Fig $1 \mathrm{H}$.

F. Longitudinal variation of the serum proteome for all 31 COVID-19 patients. Pearson correlation coefficients were calculated between the first (day 0 ) and each consecutive sampling day as shown by example in (D). The trajectory of the median Pearson correlation coefficient is highlighted in red.

different complement factors and LGALS3BP (Fig 4B, Table EV8). These reflect down-regulation of the immune system in the course of hospitalization at the level of individual proteins. Cluster 2 contained proteins associated with lipid homeostasis, including APOA1, APOA4, APOC1, APOC2, APOC3, PON1 and PLTP. Moreover, proteins involved in coagulation such as FN1, F13B and K-dependent protein C (PROC) were also increased and members of this cluster. Cluster 3 revealed partly similar trajectories as cluster 2 but decreasing levels towards the later time points. It also contained coagulation associated proteins such as $\mathrm{APOH}$, VWF, HRG and several proteases with functions in the regulation of blood coagulation such as kininogen-1 (KNG1), plasminogen (PLG) and carboxypeptidase B2 (CPB2). This is in line with previous reports of coagulopathies (in particular over-activity of this system) as one of the main complications in COVID-19 but adds a temporal and molecular dimension. With 20 proteins, immunoglobulins constitute the largest group in cluster 3.

In order to explore the extent of proteome changes over time on an individual patient basis, we calculated Pearson correlation coefficients of serum proteomes between the first (day 0) and all consecutive sampling days. This is shown by example for one person from day 0 to day 2 and day 0 to day 18 (Fig 4D). As expected, correlation between day 0 and 2 is higher than between day 0 and 18 ( 0.96 vs. $0.83)$. The scatter plots also confirm that this divergence is different for the three clusters according to their overall trajectories. In particular, CRP and SAA1 are members of cluster 1 and their levels decreased up to 1000 -fold over time. Integrating these binary proteome comparisons for a typical individual patient reveals a remarkable stability of the individual serum proteomes on consecutive days, while changes over more than a week are much more substantial (Fig 4E). Finally, the Pearson correlation coefficients for all patients over time decrease from a median correlation of 0.96 on day 1 to 0.88 from day 10 on (Fig 4F).

Focusing on the 25 patients that survived COVID-19 infection compared to the six that did not, levels of 14 proteins were different at the last day of sampling. These 14 proteins included factors of the coagulation system such as heparin cofactor 2 (SERPIND1), plasma kallikrein (KLKB1) and PLG. The latter two proteins showed longitudinal alterations in cluster 3 , emphasizing the importance of the coagulation system in COVID-19. Interestingly, the isoform Q14626 of ITIH4, a pro-inflammatory acute phase protein that has already been implicated in bacterial infection (Ma et al., 2021), was significantly increased in patients that did not survive ( $p: 2.8^{*} 10^{-6} ; 2.8$-fold) already at the first day of sampling, raising the possibility of prospective classification of disease mortality.

\section{Global correlation map of 720 proteomes}

To better understand the overall associations of all 502 quantified proteins with each other and the 19 clinical parameters of our cohort, we generated a global correlation map (Albrechtsen et al., 2018). This consists of the pairwise correlation of 521 items in all 720 samples $(135,460$ correlation coefficients) that were subjected to unsupervised hierarchical clustering (Fig 5A). This 
medRxiv preprint doi: https://doi.org/10.1101/2021.02.22.21252236; this version posted February 23, 2021. The copyright holder for this preprint (which was not certified by peer review) is the author/funder, who has granted medRxiv a license to display the preprint in perpetuity. All rights reserved. No reuse allowed without permission.
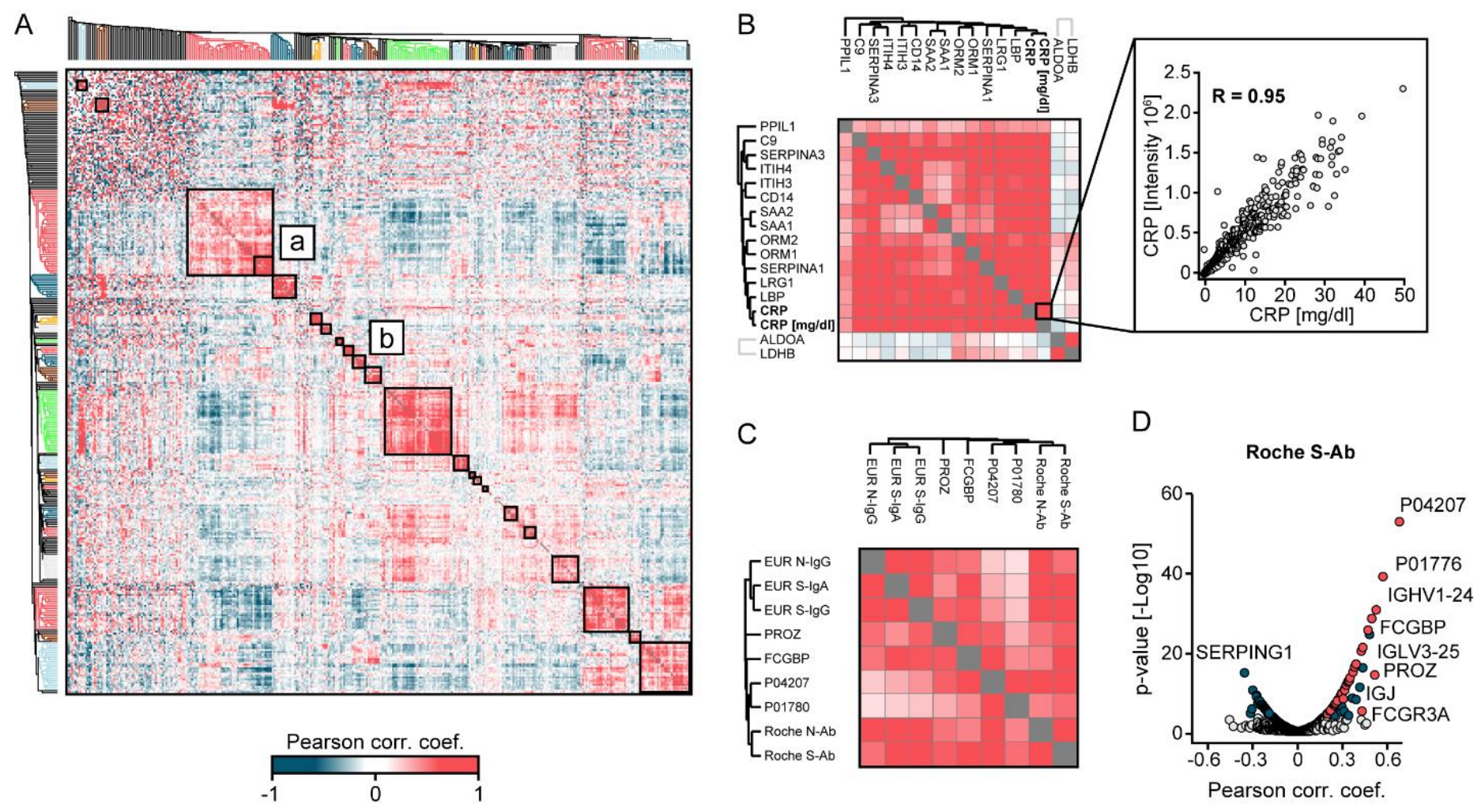

Fig 5 - Clusters of co-regulated proteins from the global correlation map

A. Global correlation map of proteins and clinical chemistry parameters based on hierarchical clustering using Euclidean distance. The cluster designated as (a) contains inflammation proteins and (b) proteins correlating with SARS-CoV-2 antibody immunoassay values. Colored sections of the dendrogram highlight clusters of co-regulated proteins.

B. Magnification of sub-cluster (a). The zoom-in on the right depicts the correlation between MS-determined CRP and clinical chemistry determined CRP.

C. Magnification of the cluster containing the five SARS-CoV-2 antibody immunoassay values and their correlating proteins from the global correlation map of all COVID-19 patients. The cluster predominantly contains immunoglobulin regions.

D. Proteins correlating with the Roche S-Ab test. Significantly correlated proteins are highlighted in blue and significantly correlated immunoglobulin regions are highlighted in red $\left(q<0.05 ; p<10^{-4}\right)$.

highlighted 21 positively or negatively correlated groups of proteins and clinical chemistry parameters (Table EV9).

The inflammation system formed the largest cluster with 71 items. CRP values as quantified by a standard clinical chemistry test showed the highest coefficient of correlation (R: 0.95) with MS-quantified CRP, providing a positive control for our workflow (Fig 5B).

Notably, FN1 and $\mathrm{APOH}$, which were among the most significantly different proteins between the first time point of COVID-19 patients and PCR-negative controls and were also longitudinally regulated, fall all into the same main cluster. Furthermore, they clustered with eight proteins connected to blood coagulation: CPB2, F2, F12, F13B, PLG, KNG1, SERPIND1 and KLKB1, further tying coagulation processes to the time course of COVID-19 at the systems-wide level. The second largest cluster of 52 items was dominated by immunoglobulins and consisted of several strongly co-regulated sub-cluster of antibodies, containing specific immunoglobulin regions. Note that our MS-based proteomics workflow does not de-novo sequence each antibody, but readily distinguishes antibody classes from each other based on peptide sequences of constant domains. 
medRxiv preprint doi: https://doi.org/10.1101/2021.02.22.21252236; this version posted February 23, 2021. The copyright holder for this preprint (which was not certified by peer review) is the author/funder, who has granted medRxiv a license to display the preprint in perpetuity.

All rights reserved. No reuse allowed without permission.

Research Article

Serum protein trajectories in COVID-19

The cohort was extensively tested by five different SARSCoV-2 antibody immunoassays, which grouped very closely together. However, they did not fall into the immunoglobulin cluster on the global correlation map, possibly due to the PCR-negative control patients. In agreement with this hypothesis, a second global correlation map limited to COVID-19 positive patients indeed clustered SARS-CoV-2 antibody immunoassays together with the immunoglobulin area (Fig $5 \mathrm{C}$ ). Of the 49 proteins with a positive correlation to the Roche S-Ab test, 34 belonged to different antibody classes ('immunoglobulin domains', Fig 5D). A similar number of correlations with immunoglobulin regions was identified for the other SARS-CoV-2 antibody immunoassays (Fig EV4A-E, Table EV10).

\section{Antibody expression during seroconversion in COVID-19}

The five SARS-CoV-2 antibody immunoassays resulted in positive responses - indicating seroconversion - in most but not all COVID-19 patients (Fig 6A). The time courses of all patients show orders of magnitude differences in immune response as indicated by the Roche S-Ab immunoassay (Fig 6B, Fig EV5A-F for all tests). To investigate the association of MS-quantified immunoglobulin regions with the five SARS-CoV-2 antibody immunoassays, we selected the five most significantly correlating serum proteins of each assay. This resulted in nine immunoglobulins and four nonimmunoglobulin proteins (FCGBP, PROZ, FN1, ITIH4), whose correlation to each of the test is shown in Fig 6C. The antibody chain Ig kappa chain V-III region CLL (P04207) was the protein with the highest significant correlation to the Roche S-Ab test ( $\left.p: 2.3^{*} 10^{-53} ; \mathrm{R}: 0.67\right)$, but showed little correlation to the EUR S-lgG, EUR N-lgG and EUR S-lgA tests $(R<0.30)$ (Fig $6 \mathrm{C})$. The immunoglobulin $\mathrm{J}$ chain (IGJ) (p: 2.9*10-28; R: 0.48) and the Ig alpha-1 chain $C$ region (IGHA1) (p: 1.2*10-23; R: 0.45) highly correlated to the EUR S-IgA assay, which detects immunoglobulin IgA, providing positive control for the serum proteomics measurements. Our unbiased approach clearly associates a large number of specific antibody regions to SARS-CoV2 infection. Furthermore, it also implicates other proteins, such as FCGBP, which binds constant regions of IgGs and has mainly been described in tissue contexts (Johansson, Thomsson and Hansson, 2009).

To investigate how our data resolves individual-specific and protein-specific courses of antibody development, we correlated immunoglobulin regions with SARS-CoV-2 antibody immunoassay levels within each patient. This is exemplified for patient 11 , where we separately plot the Roche $S-A b$ values against the levels of the four most correlating serum proteins. For each of these, seroconversion happened between day 6 and 8 (Fig 6D). While seroconversion always tends to happen within a few days, the time points varied for different patients.

To obtain a global view of the composition of the antibody response detected by the five SARS-CoV-2 antibody immunoassays, we determined the number of significantly correlating immunoglobulin regions for each test and patient (Fig 6E). With the exception of patients 13, 17 and 22, we found at least one immunoglobulin domain significantly correlating with at least one of the five tests. There were no correlations for patient 17 because none of the antibody tests were significant. Only in seven patients, all five antibody tests were associated with significantly changing immunoglobulins. Interestingly, we found correlating immunoglobulin regions even in cases where the test results had not exceeded the clinical cutoff values (marked by $X$ in the panel). This is illustrated for patient 15 , where we found 28 significantly correlating proteins with the EUR S-lgG assay, although this test itself was not above the cutoff (Fig EV6A-D). In total, 24 patients had significant correlations of immunoglobulin regions with the Roche SAb test, while only 14 individuals had significant correlations with the EUR S-IgA test (Fig 6F, Fig EV7A-D). The maximum number of correlating immunoglobulins with the Roche S-Ab assay within an individual was 49 (mean: 11). This was not a function of the number of samples per patient (Fig 6F). Significantly correlating immunoglobulins increased on average 4.3-fold, but certain immunoglobulin regions were more than 100 -fold elevated.

Next, we investigated the distribution of significantly correlating immunoglobulin regions in the study population. For this purpose, we counted different immunoglobulins that were significant in each individual. Taking the Roche S-Ab test as an example, the majority of antibody regions were significantly correlated in at least two individuals (Fig 6G). In total, a remarkable 92 out of the 127 quantified immunoglobulin regions were significant, indicating that the large majority of immunoglobulin regions are involved in the response to SARS-CoV-2 infection. Moreover, we identified 'favored' antibody regions that were increased in many patients such as IGHV3-15 (12 of 31 patients), IGHV1-69 (11) and IGLV3-10 (11). 
medRxiv preprint doi: https://doi.org/10.1101/2021.02.22.21252236; this version posted February 23, 2021. The copyright holder for this preprint (which was not certified by peer review) is the author/funder, who has granted medRxiv a license to display the preprint in perpetuity.

All rights reserved. No reuse allowed without permission.

A

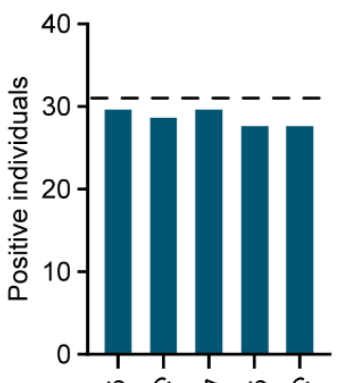

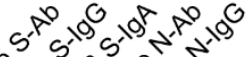

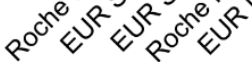

D
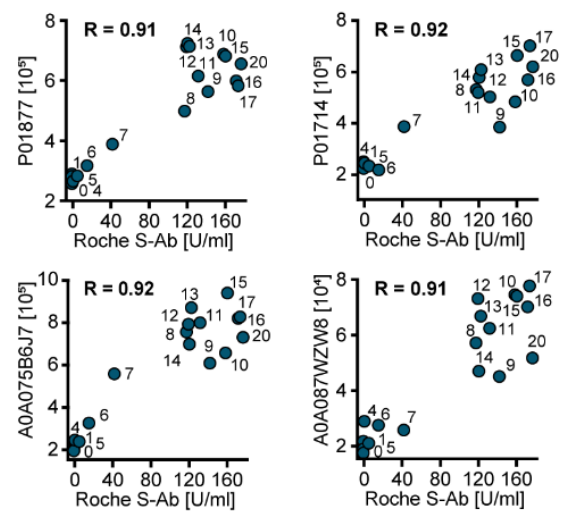

Roche S-Ab

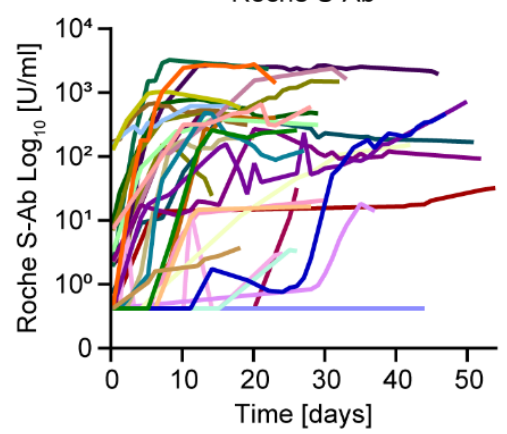

C $\quad$ Roche S-Ab $\square$ EUR S-IgG $\square$ EUR S-IgA - Roche N-Ab EUR N-IgG
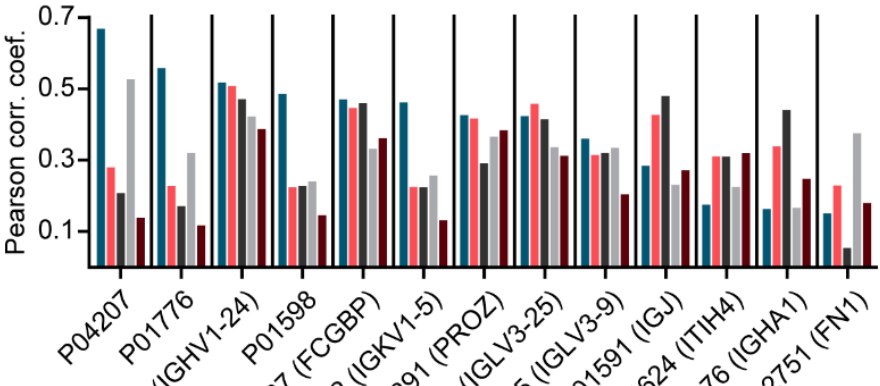

E

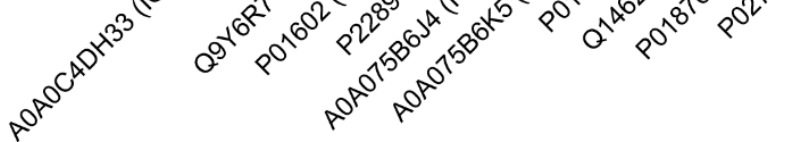

$\mathrm{F}$

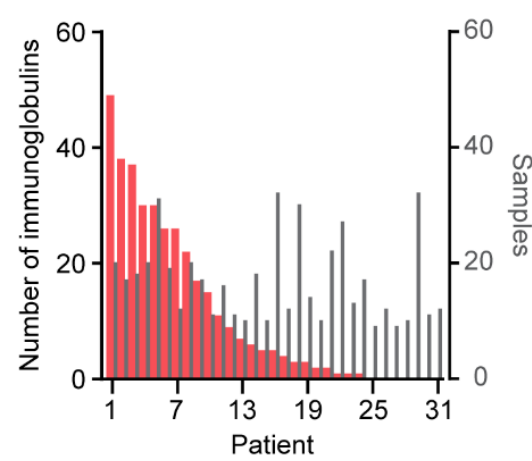

G

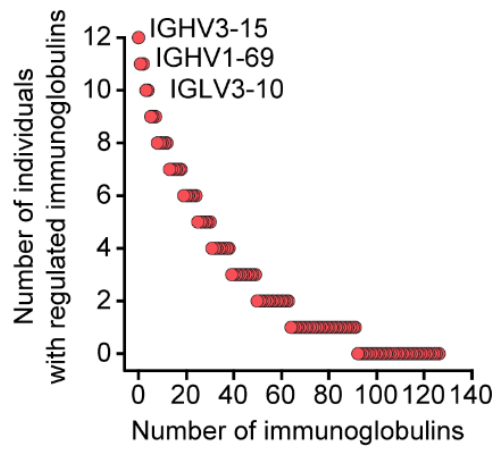

Patient 11

H $\quad 1446 \quad 81012141620$

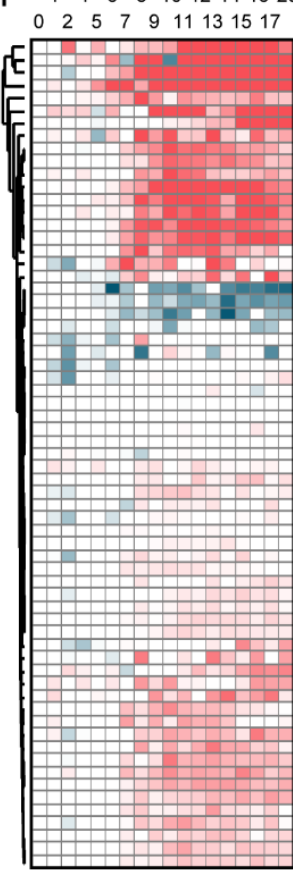

Fold-change
Patient 15

$\begin{array}{llllllllll}1 & 3 & 5 & 7 & 9 & 11 & 13 & 15 & 26\end{array}$

$\begin{array}{lllllllll}0 & 2 & 4 & 6 & 8 & 10 & 12 & 14 & 25\end{array}$

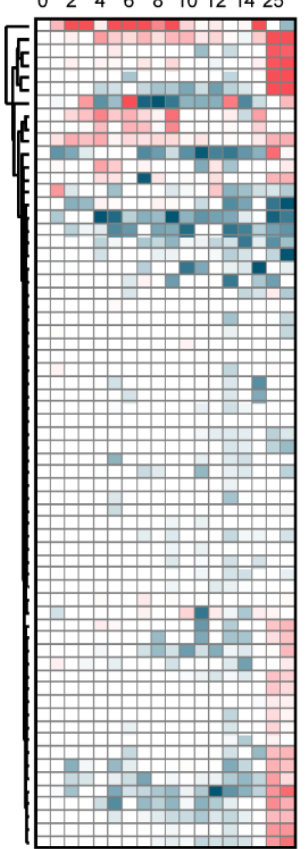

Patient 17

47111315182325303335394143 \begin{tabular}{l}
$0 \quad 510121416212426313437404244$ \\
\hline
\end{tabular}
Patient 22

$5 \quad 4042 \quad 4554$

$\begin{array}{llll}0 & 7414452\end{array}$
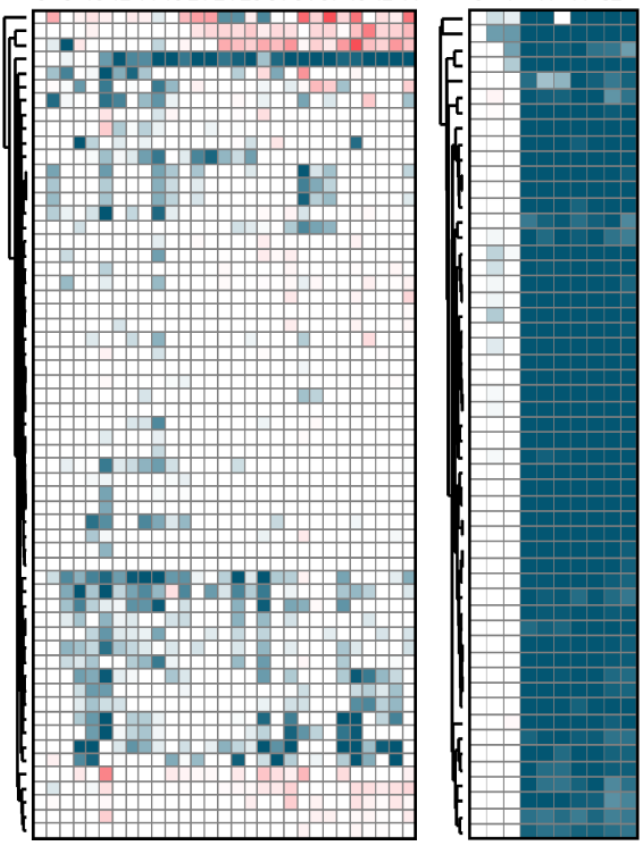
medRxiv preprint doi: https://doi.org/10.1101/2021.02.22.21252236; this version posted February 23, 2021. The copyright holder for this preprint (which was not certified by peer review) is the author/funder, who has granted medRxiv a license to display the preprint in perpetuity.

All rights reserved. No reuse allowed without permission.

Research Article

Serum protein trajectories in COVID-19

\section{Fig 6 - Dynamics of SARS-CoV-2 antibody expression during seroconversion in COVID-19}

A. Number of individuals with seroconversion as indicated by five different SARS-CoV-2 antibody immunoassays. Dashed horizontal line indicates the total number of patients.

B. Longitudinal trajectories of the Roche S-Ab immunoassay for all COVID-19 patients.

C. For each of the commercial SARS-CoV-2 antibody immunoassays, the top five correlating proteins in the serum proteome were determined, resulting in nine immunoglobulin gene products and four non-antibody proteins (x-axis).

D. Examples of correlations of four different immunoglobulin regions with the Roche S-Ab test for patient 11. Labels on the data points indicate the day of sampling. The data points of early sampling days are clustered near the origin, in contrast to later sample dates where both protein expression values and Roche S-Ab values are many-fold increased, which is consistent with seroconversion. The Pearson correlation coefficient $(R)$ is displayed.

E. Panels for each COVID-19 patient indicate the number of proteins significantly correlating with each of the five SARS-CoV-2 antibody immunoassays. The $\mathrm{X}$ indicate immunoassay measurements not exceeding the cutoff that classifies an individual as having produced antibodies against SARS-CoV-2.

F. Ranked numbers of significantly correlated immunoglobulin regions per individual are shown in red (left y-axis). Numbers of samples are shown in grey (right y-axis).

G. Immunoglobulin regions correlating with the Roche S-Ab test in the indicated number of individuals (y-axis).

$\mathrm{H}$. Time-resolved trajectories of consistently quantified immunoglobulins exemplified with patients $11,15,17$ and 22 . Hierarchical clustering grouped trajectories of immunoglobulin regions by Euclidean distance. The columns are arranged by sampling date. The time points are indicated in days above the heatmaps.

Finally, we analyzed the time course of all patients without recourse to the antibody tests. This resulted in a very detailed picture of seroconversion, in which highly correlated immunoglobulin regions clustered closely together (Fig 6H). Even within an individual the number of immunoglobulin regions, their fold-changes and time points of increasing levels varied. Note that our MS-based proteomics workflow identifies several peptides per immunoglobulin, sufficient to assign them to immunoglobulin regions while not revealing their complete sequence. Clusters of trajectories of immunoglobulin regions presumably indicate a common antigen, in this case virus proteins. Interestingly, we observed a general decrease in the levels of specific immunoglobulin regions in several individuals. One of these, the IgM constant domain, reports on the class switch of IgM to IgG directly from the proteomics data.

As expected from the readouts of the SARS-CoV-2 antibody immunoassays (Fig 6B), the immunoglobulin trajectories were highly individual-specific. In patient 11 , for example, 33 immunoglobulin regions increased over time, which grouped in two clusters with an average of 4.2- and 2.1-fold increase (Fig 6H). We found that MS-based proteomics provided additional insights in patients with very low SARS-CoV-2 antibody immunoassays values. Although these values were very low in patient 15 , we identified two clusters of immunoglobulin regions which increased on average 5.6- and 2.0-fold, allowing this patient's antibody response to be tracked by longitudinal MS-based proteome profiling. Remarkably, in patient 17 , who had no positive SARS-CoV-2 antibody immunoassays (but was PCR positive), two immunoglobulin regions increased two-fold (A0A087WUS7: p: $2.6^{*} 10^{-4}$; P01708: p: $1.9^{*} 10^{-4}$ ) after which their levels stayed elevated. SARS-CoV-2 antibody immunoassays were negative twice and three times just above threshold for patient 22. MS-based proteomics explained these borderline results as the 53 immunoglobulin regions of this patient dropped on average 5.6-fold compared to the first time points of sampling and indicated a strong effect on the adaptive immune system.

\section{Discussion}

Here, we describe alterations of the serum proteome during COVID-19 in an untargeted manner using a scalable plasma proteome profiling workflow. With a total of 720 serum samples, this is one of the largest MS-based body fluid proteomics efforts, comprising the most detailed longitudinal protein trajectories during hospitalization (average 31 days; maximum 54 days). Furthermore, the comparison of serum proteomes to a control cohort of patients with COVID-19-like symptoms that turned out to be PCR-negative, allowed further interpretation of virus induced alterations. 
medRxiv preprint doi: https://doi.org/10.1101/2021.02.22.21252236; this version posted February 23, 2021. The copyright holder for this preprint (which was not certified by peer review) is the author/funder, who has granted medRxiv a license to display the preprint in perpetuity.

All rights reserved. No reuse allowed without permission.

Research Article

Serum protein trajectories in COVID-19

As a main finding, a quarter of quantified serum proteins (130 of $502 ; 26 \%$ ) changed significantly over the disease course, revealing an extensive remodeling of the serum proteome in COVID-19. Confirming this, a study investigating the time course of the plasma proteome during COVID-19 found a comparable portion of protein changes (89 of 309; 29\%) (Demichev et al., 2020).

In our study, three clusters of co-regulated proteins with different longitudinal protein trajectories stood out: The first cluster comprised proteins decreasing during hospitalization, the second comprised proteins increasing, and the third cluster comprised proteins increasing within the first three weeks and decreasing afterwards. Serum proteome changes were striking not only on the cohort level, but just as much at the individual level. The latter could also been as seen from the individual trajectories of serum proteome remodeling.

The first cluster of longitudinally altered proteins included predominantly proteins of the innate immune system, which decreased during the first days and remained low, indicating a general decline of the immune system response during hospitalization. This observation has been confirmed by longitudinal studies of inflammatory markers determined by routine clinical chemistry, and immunoassays (Haljasmägi et al., 2020). The global correlation map with an unbiased hierarchical clustering to group proteins with the same regulation across COVID-19 positive and negative patients further confirmed the strong systemic effect on the inflammation system. The reaction of the adaptive immune response was indicated by increasing levels of specific antibody regions and SARS-CoV-2 antigen antibodies.

The second cluster, comprising proteins which increased over the course of COVID-19, consisted of proteins associated with lipid homeostasis and coagulation. Changes of proteins related to coagulation and plasma apoprotein levels were corroborated by previous work (Demichev et al., 2020). Coagulopathies are a main complication in COVID-19, calling for a detailed understanding of mechanisms of hypercoagulability via identification of proteins regulated in these processes (Demichev et al., 2020; Gupta et al., 2020; Kollias et al., 2020).

The third cluster followed a particularly interesting pattern of protein levels, which increased initially and then decreased during hospitalization. This cluster consisted mostly of immunoglobulins, which have not been reported in previous work. Several of the immunoglobulin chains that we found as regulated during seroconversion have more recently been removed from Ensembl and subsequently from the UniProt Knowledgebase, but are still available in UniParc (https://www.uniprot.org/uniparc) (UniProt Consortium, 2018; The UniProt Consortium, 2021). Their inclusion was crucial to our study, which would otherwise have resulted in a much lower number of regulated immunoglobulin regions. More generally, studies of infectious diseases with seroconversion could be applied to confirm and curate public databases. We further extensively characterized the immune response of our cohort by five different immunoassays meant to detect antibodies against the $\mathrm{N}$ and S-antigens of SARS-CoV-2. These were correlated with different types of immunoglobulin regions as quantified by our untargeted proteomics measurements. From the MS-based proteomics data, we further constructed individual-specific time-resolved trajectories of the levels and composition of antibody regions. We found highly individualized responses, but also discovered regions prominently regulated across individuals. Additionally, we found in some patients a disagreement between the quantitative signal of longitudinally regulated immunoglobulin regions identified by MS compared to the SARS-CoV-2 antibody immunoassay measurements. In one case, the SARS-CoV-2 antibody immunoassays resulted in very limited signals, however, MS-based proteomics reported on an increase of a broad spectrum of immunoglobulin regions with fold-changes similar to patients with highly positive responses in the immunoassays. Of note the different SARS-CoV-2 antibody immunoassays had also a distinct degree of variation in terms of fold-changes and correlations to each other (Buchholtz et al., 2021). Hence, the MS readout of the highly detailed immunoglobulin profile could be applied to track seroconversion in patients. In addition to antibody regions, IgGFc-binding protein (FCGBP) prominently correlated with SARS-CoV-2 antibodies. The function of FCGBP is poorly understood and has previously been reported as elevated in serum of patients with autoimmune disease (Kobayashi et al., 2001). We found levels of circulating FCGBP to be regulated during seroconversion in our COVID-19 data and we speculate that it is an indicator of antibody response. This would allow studying the immune response to COVID-19 in a quantitative fashion for each individual and to identify those that produced strong antibody responses and that could serve as donors for production of convalescent serum/plasma therapeutics (Amanat et al., 2020). 
medRxiv preprint doi: https://doi.org/10.1101/2021.02.22.21252236; this version posted February 23, 2021. The copyright holder for this preprint (which was not certified by peer review) is the author/funder, who has granted medRxiv a license to display the preprint in perpetuity.

All rights reserved. No reuse allowed without permission.

Research Article

Serum protein trajectories in COVID-19

Adding to longitudinal trajectories, we also performed a comparison of proteomes of PCR-negative controls with COVID-19-like symptoms. This analysis revealed that HRG, FN1 and APOH were among the most significantly regulated proteins showing decreased expression in COVID-19 patients at the first day of sampling. Our results point towards a complex rearrangement of multiple factors of the coagulation system, in which many of these proteins decrease at earlier time points and increase during disease course towards the levels of PCR-negative controls.

Our work emphasizes the value of longitudinal study design for biomarker discovery, which allowed to correct for interindividual variation and determination of proteome alterations in disease progression. Compared to studies with single time points between COVID-19 patients and controls that provided first insights into potentially regulated proteins, our comparison of serum proteomes over the course of disease progression, provided a clear set of potential biomarkers which we are now following up in larger cohorts.

\section{Materials and Methods}

Study cohort - COVID-19 patients: Serum samples from 31 COVID-19 patients, admitted to the University Hospital of LMU Munich with acute COVID-19 confirmed by positive PCR, were collected over time from leftover material of samples submitted to the Institute of Laboratory Medicine for routine laboratory diagnostics. Serial samples were collected from each patient, covering a period of up to 54 days from the first day of sampling, adding up to a total of 458 samples. The cohort partially overlapped with a cohort described in our previous work (Buchholtz et al., 2021). Clinical and clinical chemistry data were retrieved from electronic patient records. The patients were sampled at both regular wards and intensive care units.

PCR-negative control patients: Serum samples from 262 patients, admitted to the University Hospital of LMU Munich with possible symptoms of SARS-CoV-2 but with a negative PCR result were collected from leftover material of samples submitted to the Institute of Laboratory Medicine for routine laboratory diagnostics. SARS-CoV-2 symptoms included fever, cough, shortness of breath, throat pain, loss of smell and taste, fatigue, general malaise, gastrointestinal complaints, headache, cognitive impairment, need of oxygen or intensive care treatment because of respiratory symptoms.
Samples were stored as $250 \mu$ laliquots in 2D barcoded biobanking vials (Thermo Scientific, Waltham, Massachusetts, USA) at $-80^{\circ} \mathrm{C}$ in the LMU LabMed Biobank. Anonymized analysis has been approved by the Ethics Committee of LMU Munich (reference number 210047).

Sample preparation - Plasma samples were prepared for LC-MS/MS analysis as previously published (Geyer, Kulak, et al., 2016). In brief, plasma proteins were denatured, alkylated, digested and peptides purified using an automated liquid handling platform (Agilent Bravo) in a 96 well format. To generate a spectral library, 20 plasma samples were pooled and fractioned into 24 fractions using high $\mathrm{pH}$-reversed phase liquid chromatography.

LC-MS/MS analysis - Digested peptides were separated online via a nanoflow reversed-phase chromatography with an Evosep One liquid chromatography (LC) system (Evosep). Peptides were separated on an $8 \mathrm{~cm} \times 150 \mu \mathrm{m}$ column packed with $1.9 \mu \mathrm{m}$ ReproSil-Pur C18-AQ particles (Dr. Maisch) using the 60 SPD method with a gradient length of 21 minutes. The Evosep One was coupled online to a timsTOF Pro mass spectrometer (Bruker Daltonics). The instrument was operated in the DDA PASEF mode with 10 PASEF scans per acquisition cycle and accumulation and ramp times of $100 \mathrm{~ms}$ each. Singly charged precursors were excluded, the 'target value' was set to 20,000 and dynamic exclusion was activated and set to $0.4 \mathrm{~min}$. The quadrupole isolation width was set to $2 \mathrm{Th}$ for $\mathrm{m} / \mathrm{z}<700$ and 3 Th for $\mathrm{m} / \mathrm{z}>800$.

Data analysis - MS raw files were analyzed by MaxQuant software, version 1.6.17.0 (22) and MS spectra were searched against the reference proteome FASTA file, downloaded from https://www.ebi.ac.uk/reference_proteomes/ in January 2020.

A contaminant database generated by the Andromeda search engine (23) was configured with cysteine carbamidomethylation as a fixed modification and $\mathrm{N}$ terminal acetylation and methionine oxidation as variable modifications. We set the false discovery rate (FDR) to 0.01 for protein and peptide levels with a minimum length of 7 amino acids for peptides and the FDR was determined by searching a reversed sequence database. Enzyme specificity was set as C-terminal to arginine and lysine as expected using trypsin and $\mathrm{Lys} C$ as proteases. A maximum of two missed cleavages were allowed. All proteins and peptides matching the reversed database were filtered out. 
medRxiv preprint doi: https://doi.org/10.1101/2021.02.22.21252236; this version posted February 23, 2021. The copyright holder for this preprint (which was not certified by peer review) is the author/funder, who has granted medRxiv a license to display the preprint in perpetuity.

All rights reserved. No reuse allowed without permission.

Research Article

Serum protein trajectories in COVID-19

Bioinformatics analysis - Bioinformatics analyses were performed in Jupyter notebooks using Python and with the Perseus software of the MaxQuant computational platform (22, 24). Two-sample t-tests were performed for the comparison of different groups. For two-sample tests, we used a two-sided Student's t-test and used a permutationbased FDR (0.05) for multiple hypothesis testing. Twosample tests were performed to identify protein level differences of PCR-negative patients with COVID-19-like symptoms and COVID-19 patients at the first day of sampling and at the time point with the highest Roche S-Ab test response.

Longitudinal alterations of protein levels - To identify proteins correlating with disease severity, we first Z-scored proteins within each individual to take individual-specific protein levels into account. To consider each disease state only once per patient, we averaged the Z-scores within each disease state in each individual and applied them to the correlation analysis. Pearson correlation coefficients were calculated for correlation analysis and permutation-based FDR (0.05) was applied for multiple hypothesis testing. Zscored protein levels were applied for the correlation of protein levels to the time course of sampling for which each time point was used.

One-sample t-tests were applied to identify longitudinally altered protein levels between two time points. First, the difference of protein levels between both time points were calculated on log10 transformed data to take individualspecific protein levels into account. This was performed to calculate the difference of the first day of sampling and the sample with the highest Roche S-Ab test response.

One-sample t-tests were also applied to identify longitudinally altered protein levels between the first day of sampling and binned time intervals. For this purpose, we normalized the protein levels by referencing to the first day of sampling to take individual-specific protein levels into account. Next, we averaged the normalized values for fiveday intervals (day 1-5, 6-10, ...) and applied a one-sample t-test to identify proteins significantly different between the first time point and the median of the intervals. A BenjaminiHochberg FDR (0.05) has been applied for multiple hypothesis testing.

Quality assessment - The evaluation of sample quality has been performed according to recently described quality marker panels (Geyer et al., 2019). In short, summed intensities of each of three quality marker panels for erythrocyte lysis, platelet contamination and coagulation have been calculated in addition to the intensities of all nonquality associated proteins. The percentage of the intensities of the quality marker panels compared to nonquality associated proteins were calculated to determine the contamination of each sample. If the percentage of erythrocyte protein intensities compared to the total proteome was $>6 \%$, a sample was flagged as having increased erythrocyte proteins. If the percentage of platelet protein intensities compared to the total proteome was $>0.5 \%$, a sample was flagged as having increased platelet contamination. If the percentage of fibrinogen chains was $>0.3 \%$, a sample was flagged as having impaired coagulation. Coagulation of serum samples was impaired according to the quality marker panel in 17 samples of COVID-19 patients compared to just one control sample. A total of 15 out of the 17 samples of COVID-19 patients originated from the same individual.

Potential bias between groups was assessed by highlighting the three quality marker panels in a volcano plot of the comparison of the two groups (Fig EV2). Potential bias was indicated in the text, if present. Outliers in statistical tests that serve as candidates within this manuscript were assessed for potential co-correlations with platelet and erythrocyte markers. As MS-based proteomics is unbiased in the selection of proteins for evaluation, we report on a broad scope of information that we can use to evaluate potential outlier proteins in more detail. Herein, we used the quality marker panels for further evaluation of statistically significant outlier. The quality marker panel indicated a bias towards increased erythrocyte proteins in controls, which was reflected in the results comparing COVID-19 positive and negative patients with significant proteins of typical erythrocyte proteins such as the hemoglobin chains HBA1, HBB and HBD and the bias of quality marker proteins in one side of the t-test (Fig EV2AC). In the same vein, we reported previously (Geyer et al., 2019) that GSN can be an indicator for platelet contamination. However, other platelet markers were not enriched in controls and a global correlation analysis revealed that GSN was not co-regulated with other platelet markers in this study, confirming that GSN changed due to COVID-19 infection. Of all significantly regulated proteins, only hemoglobin chains clustered within quality marker panels, indicating that they originated from erythrocytes.

Protein trajectories - Significantly longitudinally regulated proteins were defined as proteins that have a statistically significant difference between the first time sampling time points and other time points. Samples were available for 
medRxiv preprint doi: https://doi.org/10.1101/2021.02.22.21252236; this version posted February 23, 2021. The copyright holder for this preprint (which was not certified by peer review) is the author/funder, who has granted medRxiv a license to display the preprint in perpetuity.

All rights reserved. No reuse allowed without permission.

Research Article

Serum protein trajectories in COVID-19

each COVID-19 patient at the first time point (TP 0), but not at every other time point. To increase the statistical power for the identification of longitudinally changing proteins, we binned proteomes over a distinct time window of always five days: $1-5,6-10,11-15,16-20,21-25,26-30,31-35,36-40$, $41-45,46-50,51-54$. For this purpose, we calculated the difference within each individual from the first sample to all other time points and calculated the median according to the above listed time windows. Next, we applied a onesample t-test, which resulted in 86 statistically significant proteins for all comparisons (Table EV6). Next, we selected all proteins that were statistically significant in one of the above-mentioned tests to identify longitudinally changing proteins, resulting in 130 proteins. The protein intensities were Z-scored within each individual over time. We calculated the median of the Z-scores for each time point for which we had at least five samples, resulting in 37 time points and 116 proteins fulfilling this criterion. The median Z-scores of the proteins were than subjected to a hierarchical clustering with Euclidean distance.

Intra-individual proteome remodeling - The proteome remodeling was assessed by calculating Pearson correlation coefficients between the proteome at the first time point and the other time points. The median Pearson correlation coefficient plot was calculated only for time points with samples of at least five individuals, hence, covering up to 37 days.

Keyword annotation of regulated proteins - Keywords and Gene Ontology Biological Process (GOBP), Cellular Component (GOCC) and Molecular Function (GOMF) terms were added to the 116 proteins. A Fisher's exact test was applied between the Keywords and the GO terms. This resulted in 409 significant associations from 51 keywords. Keywords "3D structure", "Completeproteome", "Referenceproteome", "Polymorphism", "Directproteinsequencing", "Repeat", "Secreted", "Signal" and "Disulfidebound" were excluded due to the general nature of the terms. The keywords "Secreted" and "Signal" were combined to "Secreted", "Innateimmunity" and "Immunity" to "Immunity", "Serineprotease" and "Protease" to "Protease", "Serinproteaseinhibitor" and "Proteaseinhibitor" "Proteaseinhibitor", "ImmunoglobulinVregion" and "Immunoglobulindomains" to "Immunoglobulindomains", "Complementalternatepathway" and "Complementpathway" to "Complementpathway", "Cytolysis" and "Membraneattackcomplex" to "Membraneattackcomplex" due to their high similarity. The 20 Keywords which had the most significant associations with a GO term were selected for Fig 4A. The complete list can be found in Table EV7.

Correlation analysis - We calculated Pearson correlation coefficients of binary comparisons of proteins and/or clinical parameters. We applied a hierarchical clustering on top of the correlation matrix using Euclidean distance. Based on the clustering 21 groups of co-regulated proteins and/or clinical parameters were identified. To draft correlation plots (U-plots), the correlation of clinical to proteomics data was done with Python version 3.8.5. using Pandas (1.1.3), Numpy (1.19.2), Scipy (1.5.2) and Statsmodels (0.12.0) packages. In brief, Pearson correlation coefficients and Pearson $p$-values of protein intensity values to other numerical parameters were calculated. To address multiple testing, Benjamini-Hochberg FDR was employed for $p$ value correction.

Individual-specific immunoglobulin trajectories Immunoglobulin regions were filtered for $100 \%$ valid values within each individual. Next the time points were sorted from the first to the last day of sampling. A hierarchical clustering based on Euclidean distance was applied to group similar trajectories together. In patient 17, a two-sample t-test was performed to compare protein intensities of P01708 and A0A087WUS7 between the earlier (0-24 days) and later time points (25-44 days).

\section{Acknowledgments}

We thank in particular Britta Pauli and Babett Rannefeld for their expert technical assistance and Peter $\mathrm{V}$. Treit for editing and discussions. We further thank Elisabeth Gasteiger from the UniProt Consortium for the assessment and discussion of immunoglobulin sequences of the UniProt Knowledgebase. We also thank the entire team at OmicEra Diagnostics $\mathrm{GmbH}$ for helpful input and discussion.

\section{Funding}

The work carried out in this project was funded by OmicEra Diagnostics $\mathrm{GmbH}$ and the University Hospital of LMU Munich, and supported by the German Federal Ministry of Education and Research (BMBF) project ProDiag (grant numbers: 01KI20377A, 01KI20377B) and the German Biobank Alliance, Munich (01EY1711C). 
medRxiv preprint doi: https://doi.org/10.1101/2021.02.22.21252236; this version posted February 23, 2021. The copyright holder for this preprint (which was not certified by peer review) is the author/funder, who has granted medRxiv a license to display the preprint in perpetuity. All rights reserved. No reuse allowed without permission.

\section{Author contributions}

PEG, FA, LMH, MM and DT designed the experiments, supervised and guided the project, discussed proteomics and clinical data, and wrote the manuscript. PEG, SD, MTS, SVW, FMT, JBMR, MM and DT analyzed and interpreted MS-based proteomics data. PEG and JBMR performed and interpreted the MS-based proteomics analysis, did bioinformatics analysis generated text and figures for the manuscript. FA, MLL, MW, PE, and MB interpreted proteomics and clinical chemistry data, discussed these findings, and generated text.

\section{Conflict of interest statement}

PEG, SVW, SD, MTS, FMT and JBMR are employees of OmicEra Diagnostics GmbH.

\section{Literature}

Aebersold, R. and Mann, M. (2016) 'Mass-spectrometric exploration of proteome structure and function', Nature, 537(7620), pp. 347-355. doi: 10.1038/nature19949.

Albrechtsen, N. J. W. et al. (2018) 'Plasma Proteome Profiling Reveals Dynamics of Inflammatory and Lipid Homeostasis Markers after Roux-En-Y Gastric Bypass Surgery', Cell Systems, 7(6), pp. 601-612.e3. doi: 10.1016/j.cels.2018.10.012.

Amanat, F. et al. (2020) 'A serological assay to detect SARSCoV-2 seroconversion in humans', Nature Medicine, 26(7), pp. 1033-1036. doi: 10.1038/s41591-020-0913-5.

Bache, N. et al. (2018) 'A Novel LC System Embeds Analytes in Pre-formed Gradients for Rapid, Ultra-robust Proteomics', Molecular \& cellular proteomics: MCP, 17(11), pp. 2284-2296. doi: 10.1074/mcp.TIR118.000853.

Beck, S. et al. (2015) 'The Impact II, a Very High-Resolution Quadrupole Time-of-Flight Instrument (QTOF) for Deep Shotgun Proteomics', Molecular \& Cellular Proteomics : MCP, 14(7), pp. 2014-2029. doi: 10.1074/mcp.M114.047407.

Buchholtz, M.-L. et al. (2021) 'SARS-CoV-2 antibody immunoassays in serial samples reveal earlier seroconversion in acutely ill COVID-19 patients developing ARDS', medRxiv, p. 2021.02.15.21250916. doi: 10.1101/2021.02.15.21250916.

D'Alessandro, A. et al. (2020) 'Serum Proteomics in COVID-19 Patients: Altered Coagulation and Complement Status as a Function of IL-6 Level', Journal of Proteome Research, 19(11), pp. 4417-4427. doi: 10.1021/acs.jproteome.0c00365.

Demichev, V. et al. (2020) A time-resolved proteomic and diagnostic map characterizes COVID-19 disease progression and predicts outcome. preprint. Infectious Diseases (except HIV/AIDS). doi: 10.1101/2020.11.09.20228015.

Dodig-Crnković, T. et al. (2020) Facets of individual-specific health signatures determined from longitudinal plasma proteome profiling. $\quad$ preprint. Biochemistry. doi: 10.1101/2020.03.13.988683.

Geyer, P. E., Kulak, N. A., et al. (2016) 'Plasma Proteome Profiling to Assess Human Health and Disease', Cell Systems, 2(3), pp. 185-195. doi: 10.1016/j.cels.2016.02.015.

Geyer, P. E., Albrechtsen, N. J. W., et al. (2016) 'Proteomics reveals the effects of sustained weight loss on the human plasma proteome', Molecular Systems Biology, 12(12). doi: $10.15252 / \mathrm{msb} .20167357$.

Geyer, P. E. et al. (2017) 'Revisiting biomarker discovery by plasma proteomics', Molecular Systems Biology, 13(9), p. 942. doi: 10.15252/msb.20156297.

Geyer, P. E. et al. (2019) 'Plasma Proteome Profiling to detect and avoid sample-related biases in biomarker studies', EMBO Molecular Medicine, 11(11). doi: 10.15252/emmm.201910427.

Gupta, S. et al. (2020) 'Factors Associated With Death in Critically Ill Patients With Coronavirus Disease 2019 in the US', JAMA Internal Medicine, 180(11), p. 1436. doi: 10.1001/jamainternmed.2020.3596.

Ignjatovic, V. et al. (2019) 'Mass Spectrometry-Based Plasma Proteomics: Considerations from Sample Collection to Achieving Translational Data', Journal of Proteome Research. doi: 10.1021/acs.jproteome.9b00503.

Johansson, M. E. V., Thomsson, K. A. and Hansson, G. C. (2009) 'Proteomic analyses of the two mucus layers of the colon barrier reveal that their main component, the Muc2 mucin, is strongly bound to the Fcgbp protein', Journal of Proteome Research, 8(7), pp. 3549-3557. doi: 10.1021/pr9002504.

Kobayashi, K. et al. (2001) 'Detection of Fcgamma binding protein antigen in human sera and its relation with autoimmune diseases', Immunology Letters, 79(3), pp. 229-235. doi: 10.1016/s0165-2478(01)00288-7.

Kollias, A. et al. (2020) 'Thromboembolic risk and anticoagulant therapy in COVID-19 patients: emerging evidence and call for action', British Journal of Haematology, 189(5), pp. 846-847. doi: 10.1111/bjh.16727.

Long, Q.-X. et al. (2020) 'Antibody responses to SARS-CoV-2 in patients with COVID-19', Nature Medicine, 26(6), pp. 845-848. doi: 10.1038/s41591-020-0897-1.

Ma, Y. et al. (2021) 'ITIH4, as an inflammation biomarker, mainly increases in bacterial bloodstream infection', Cytokine, 138, p. 155377. doi: 10.1016/j.cyto.2020.155377.

Meier, F. et al. (2015) 'Parallel Accumulation-Serial Fragmentation (PASEF): Multiplying Sequencing Speed and Sensitivity by Synchronized Scans in a Trapped Ion Mobility 
medRxiv preprint doi: https://doi.org/10.1101/2021.02.22.21252236; this version posted February 23, 2021. The copyright holder for this preprint (which was not certified by peer review) is the author/funder, who has granted medRxiv a license to display the preprint in perpetuity.

All rights reserved. No reuse allowed without permission.

Device', Journal of Proteome Research, 14(12), pp. 5378-5387. doi: 10.1021/acs.jproteome.5b00932.

Meier, F. et al. (2018) 'Online Parallel Accumulation-Serial Fragmentation (PASEF) with a Novel Trapped Ion Mobility Mass Spectrometer', Molecular \& Cellular Proteomics, 17(12), pp. 2534-2545. doi: 10.1074/mcp.TIR118.000900.

Messner, C. B. et al. (2020) 'Ultra-high-throughput clinical proteomics reveals classifiers of COVID-19 infection', Cell Systems. doi: 10.1016/j.cels.2020.05.012.

Middeldorp, S. et al. (2020) 'Incidence of venous thromboembolism in hospitalized patients with COVID-19', Journal of thrombosis and haemostasis: JTH, 18(8), pp. 19952002. doi: 10.1111/jth.14888.

Nicolai, L. et al. (2020) 'Immunothrombotic Dysregulation in COVID-19 Pneumonia Is Associated With Respiratory Failure and Coagulopathy', Circulation, 142(12), pp. 1176-1189. doi: 10.1161/CIRCULATIONAHA.120.048488.

Park, J. et al. (2020) 'In-depth blood proteome profiling analysis revealed distinct functional characteristics of plasma proteins between severe and non-severe COVID-19 patients', Scientific Reports, 10(1), p. 22418. doi: 10.1038/s41598-020-80120-8.

Rodriguez-Morales, A. J. et al. (2020) 'Clinical, laboratory and imaging features of COVID-19: A systematic review and meta- analysis', Travel Medicine and Infectious Disease, 34, p. 101623. doi: 10.1016/j.tmaid.2020.101623.

Shen, B. et al. (2020) Proteomic and Metabolomic Characterization of COVID-19 Patient Sera. preprint. Infectious Diseases (except HIV/AIDS). doi: 10.1101/2020.04.07.20054585.

Shu, T. et al. (2020) 'Plasma Proteomics Identify Biomarkers and Pathogenesis of COVID-19', Immunity, 53(5), pp. 1108-1122.e5. doi: 10.1016/j.immuni.2020.10.008.

Suhre, K., McCarthy, M. I. and Schwenk, J. M. (2021) 'Genetics meets proteomics: perspectives for large population-based studies', Nature Reviews Genetics, 22(1), pp. 19-37. doi: 10.1038/s41576-020-0268-2.

The UniProt Consortium (2021) 'UniProt: the universal protein knowledgebase in 2021', Nucleic Acids Research, 49(D1), pp. D480-D489. doi: 10.1093/nar/gkaa1100.

UniProt Consortium, T. (2018) 'UniProt: the universal protein knowledgebase', Nucleic Acids Res, 46(5), p. 2699. doi: 10.1093/nar/gky092.

Wiersinga, W. J. et al. (2020) 'Pathophysiology, Transmission, Diagnosis, and Treatment of Coronavirus Disease 2019 (COVID19): A Review', JAMA, 324(8), pp. 782-793. doi: 10.1001/jama.2020.12839. 
medRxiv preprint doi: https://doi.org/10.1101/2021.02.22.21252236; this version posted February 23, 2021. The copyright holder for this preprint (which was not certified by peer review) is the author/funder, who has granted medRxiv a license to display the preprint in perpetuity.

All rights reserved. No reuse allowed without permission.

\section{Supplemental Material}

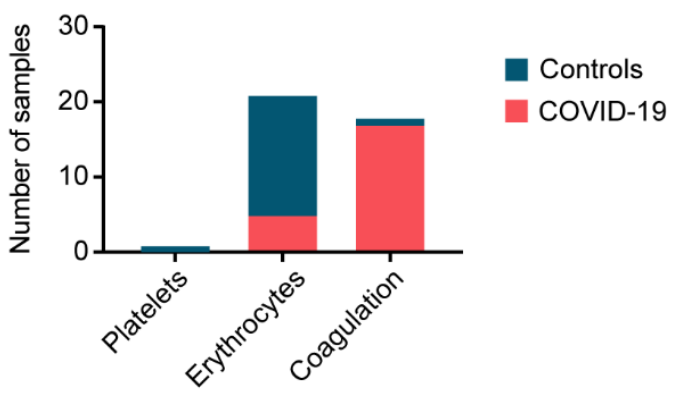

Fig EV1 - Distribution of samples with poor quality according to platelet contamination, erythrocyte contamination and coagulation in COVID-19 positive and negative patients

A

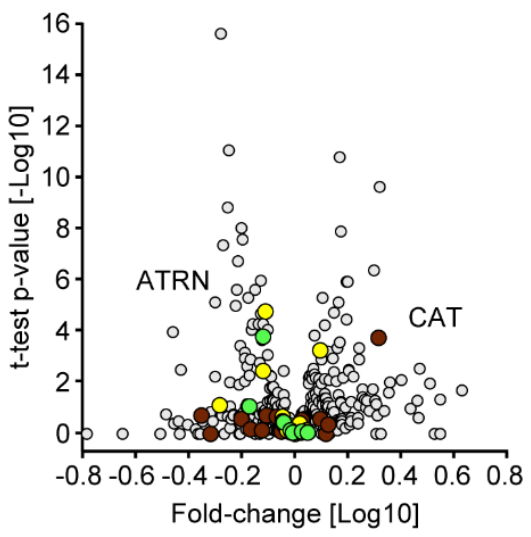

B

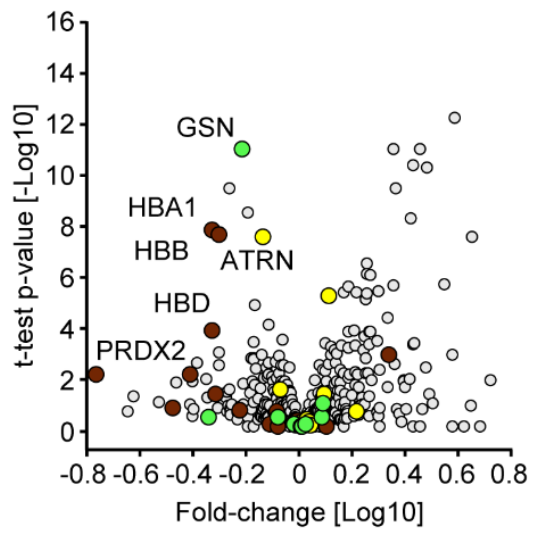

C

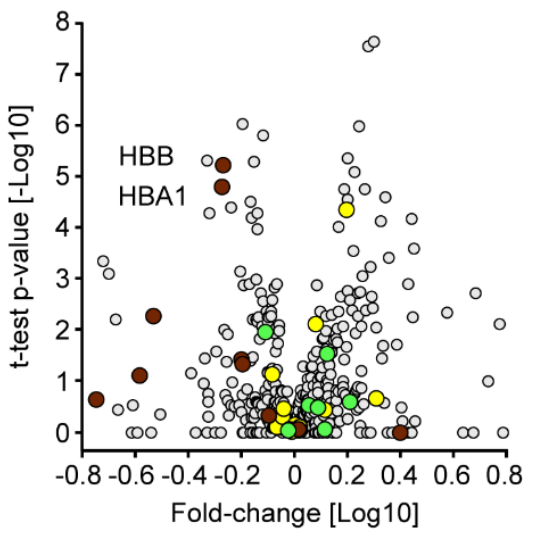

Fig EV2 - Quality marker distribution in Volcano plots

A. Comparison of the serum proteomes of 31 COVID-19 patients at the day of sampling and 262 PCR-negative controls according to Fig 2A. Erythrocyte markers are highlighted in dark red. Platelet markers are highlighted in green. Coagulation panel markers are highlighted in yellow.

B. Volcano plot comparing the serum proteomes of COVID-19 patients at the time point of the highest Roche S-Ab test response and PCR-negative controls according to Fig 2B.

C. Volcano plot of a one-sample t-test comparing the sample at day 0 and the time point with the highest antibody levels according to Fig 3B. 
medRxiv preprint doi: https://doi.org/10.1101/2021.02.22.21252236; this version posted February 23, 2021. The copyright holder for this preprint (which was not certified by peer review) is the author/funder, who has granted medRxiv a license to display the preprint in perpetuity. All rights reserved. No reuse allowed without permission.

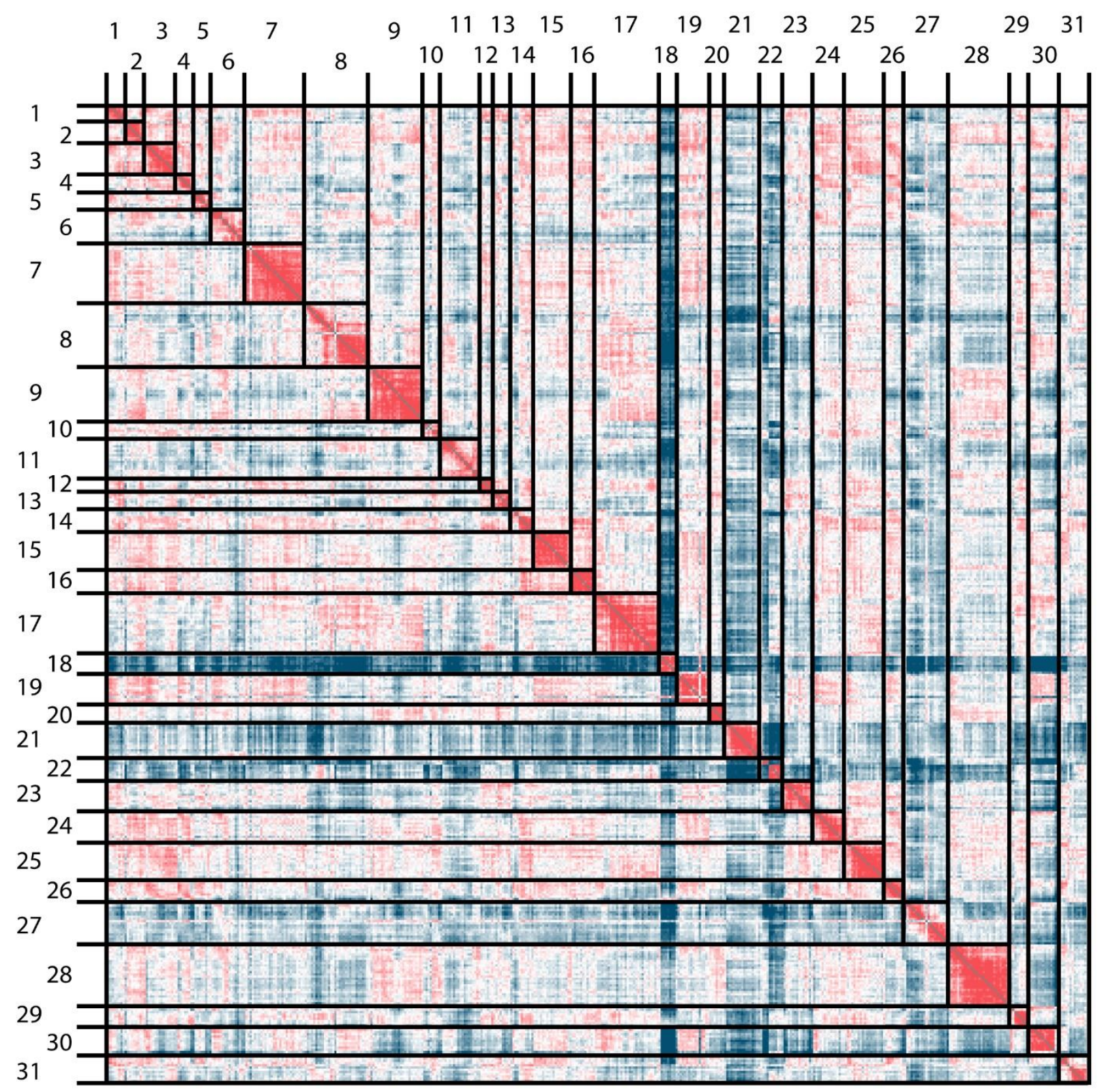

Fig EV3 - Proteome correlation of COVID-19 patients

Individuals are numbered from 1 to 31 and samples are ordered according to the day of sampling. 
medRxiv preprint doi: https://doi.org/10.1101/2021.02.22.21252236; this version posted February 23, 2021. The copyright holder for this preprint (which was not certified by peer review) is the author/funder, who has granted medRxiv a license to display the preprint in perpetuity.

All rights reserved. No reuse allowed without permission.

Research Article

Serum protein trajectories in COVID-19

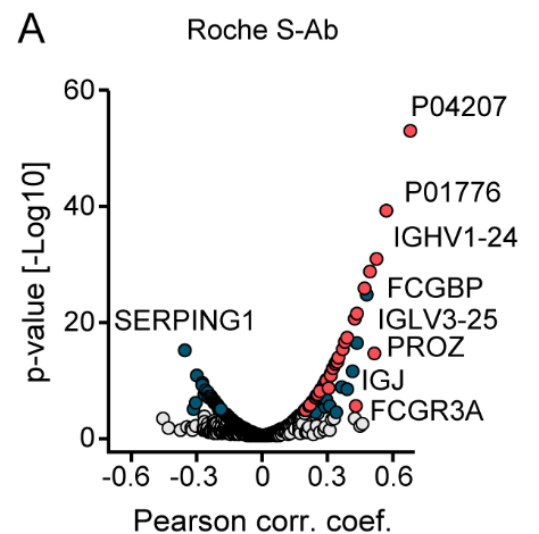

D

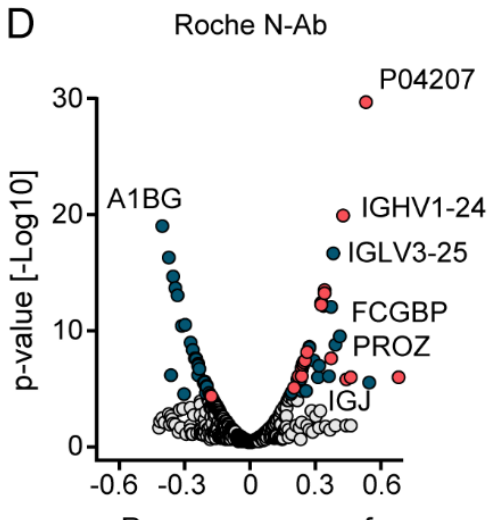

Pearson corr. coef.
B EUR S-IgG

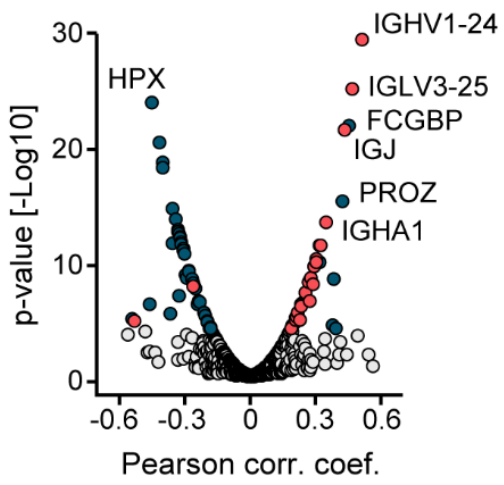

$E$

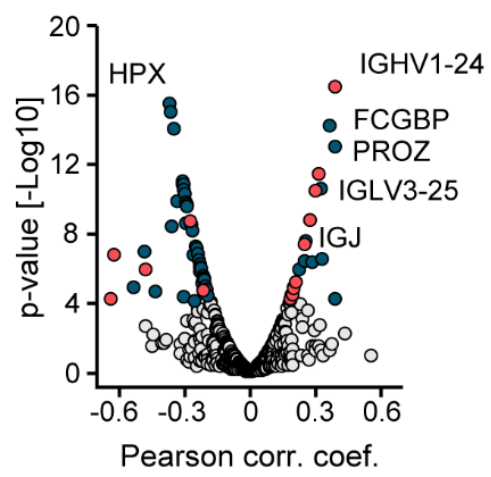

C EUR S-IgA

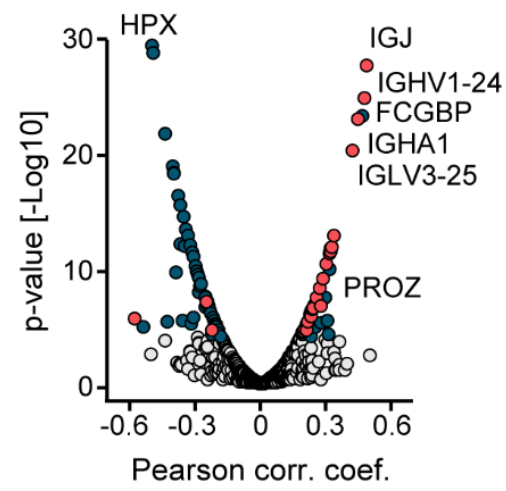

Fig EV4 - Protein correlations to SARS-CoV-2 antibody assays

A-E. Correlation analyses of proteins with Roche S-Ab (A), EUR S-IgG (B), EUR S-IgA (C), Roche N-Ab (D) and EUR N-lgG tests (E). Antibodies are highlighted in red. Other significant proteins are highlighted in blue. 
medRxiv preprint doi: https://doi.org/10.1101/2021.02.22.21252236; this version posted February 23, 2021. The copyright holder for this preprint (which was not certified by peer review) is the author/funder, who has granted medRxiv a license to display the preprint in perpetuity. All rights reserved. No reuse allowed without permission.

Research Article

Serum protein trajectories in COVID-19

A

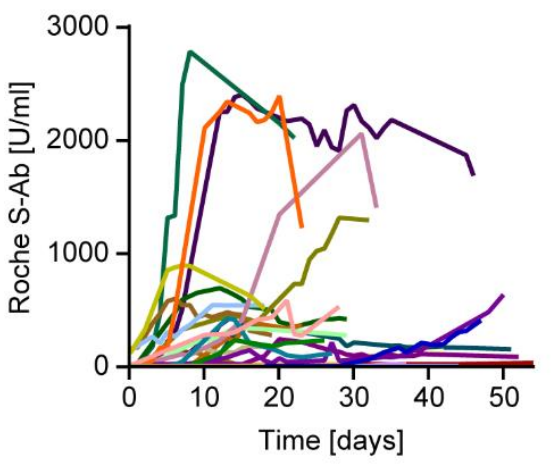

D

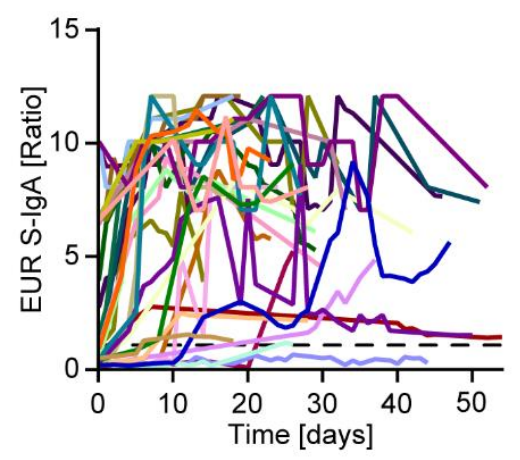

B

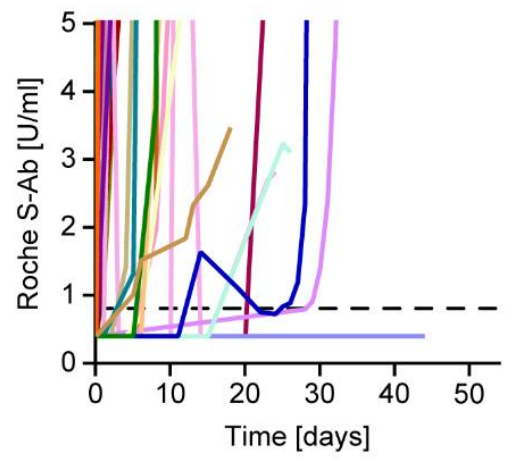

E

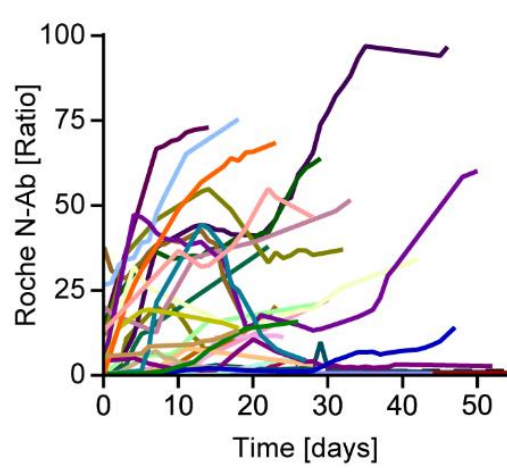

C EUR S-IgG

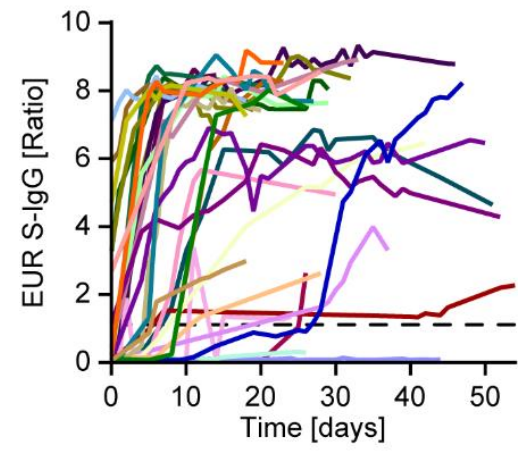

F

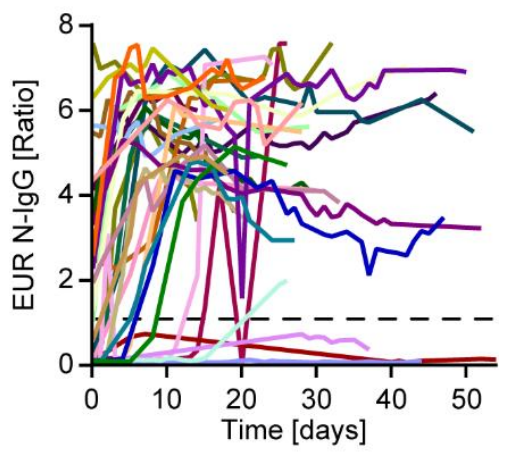

Fig EV5 - Time-resolved SARS-CoV-2 antibody immunoassay responses of COVID-19 patients

A. Trajectories of the Roche S-Ab.

B. Zoom-in of the Roche S-Ab response from (A).

C-F. Longitudinal trajectories of the EUR S-IgG, EUR S-IgA, Roche N-Ab, and EUR N-IgG test, respectively.

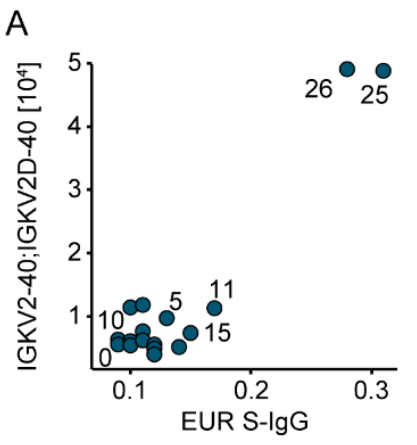

B

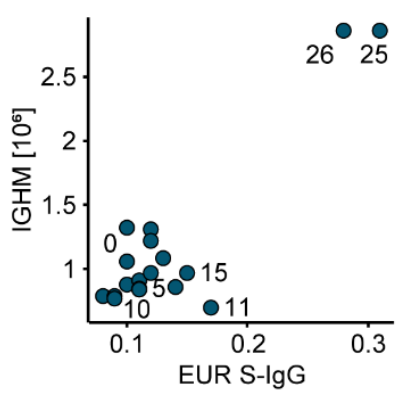

C

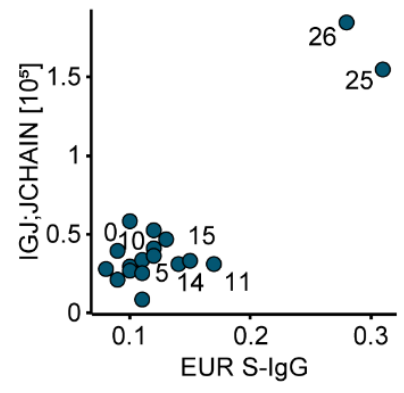

D

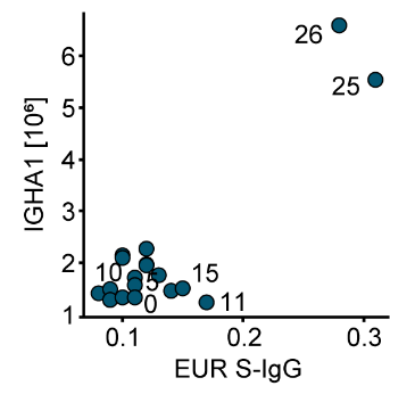

Fig EV6 - Proteins significantly correlating to the EUR S-IgG assay for patient 15

A-D. Examples of correlations of four different immunoglobulin regions measured with the EUR S-IgG test within one patient. Labels indicate the day of sampling. The data points of early sampling days are clustered near the origin, in contrast to later sample dates where both protein expression values and EUR S-IgG values are increased, consistent with seroconversion. 
medRxiv preprint doi: https://doi.org/10.1101/2021.02.22.21252236; this version posted February 23, 2021. The copyright holder for this preprint (which was not certified by peer review) is the author/funder, who has granted medRxiv a license to display the preprint in perpetuity.

All rights reserved. No reuse allowed without permission.

Research Article

A

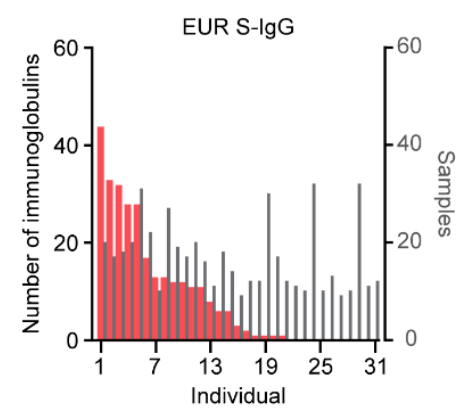

B

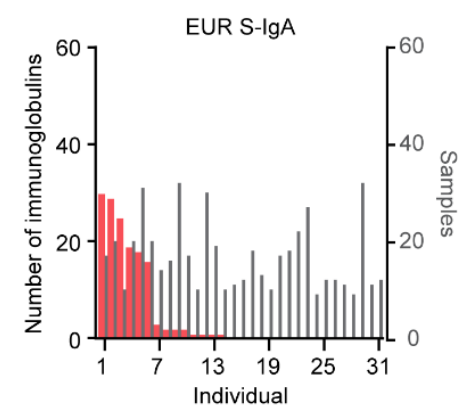

C

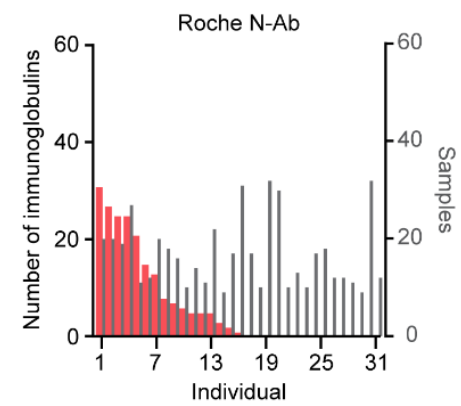

Serum protein trajectories in COVID-19

Fig EV7 - Proteins correlating to different SARS-CoV-2 antibody assays

A-D. Number of immunoglobulins significantly correlating in the indicated individuals to EUR S-lgG (A), EUR S-IgA (B), Roche N-Ab (C), and EUR N-lgG test (D). 